\title{
Cobaloxime-Based Artificial Hydrogenases
}

Marine Bacchi, ${ }^{\mathrm{a}}$ Gustav Berggren, ${ }^{\text {a\# }}$ Jens Niklas, ${ }^{\mathrm{b}}$ Elias Veinberg, ${ }^{\mathrm{c}}$ Michael W. Mara, ${ }^{\mathrm{d}}$ Megan L. Shelby, ${ }^{\mathrm{d}}$ Oleg G. Poluektov, ${ }^{\mathrm{b}}$ Lin X. Chen, ${ }^{\mathrm{b}, \mathrm{d}}$ David M. Tiede, ${ }^{\mathrm{b}}$ Christine Cavazza, ${ }^{\mathrm{a}}$ Martin J. Field, ${ }^{\mathrm{c}}$ Marc Fontecave, ${ }^{\mathrm{a}, \mathrm{e}}$ and Vincent Artero* ${ }^{\mathrm{a}}$

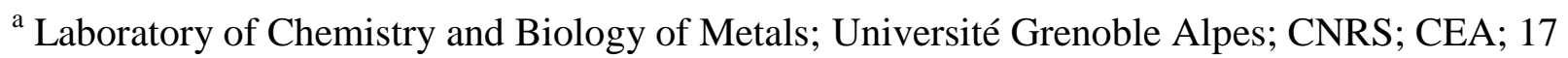
rue des Martyrs, F-38000 Grenoble, France; vincent.artero@ cea.fr +33438789106.

${ }^{\mathrm{b}}$ Chemical Sciences and Engineering Division, Argonne National Laboratory, 9700 South Cass Avenue, Lemont, Illinois 60439, USA

${ }^{\mathrm{c}}$ DYNAMO/DYNAMOP, Institut de Biologie Structurale, UMR CNRS/ Université Grenoble Alpes/CEA 5075, EPN Campus, 6 rue Jules Horowitz F-38000 Grenoble, France.

${ }^{\mathrm{d}}$ Department of Chemistry, Northwestern University, 2145 Sheridan Road, Evanston, Illinois 60208, USA

${ }^{\mathrm{e}}$ Laboratoire de Chimie des Processus Biologiques, UMR 8229 (Collège de France-CNRSUniversité Pierre et Marie Curie), 11 place Marcellin Berthelot 75005 Paris, France

\# present address: Department of Biochemistry and Biophysics, Stockholm University, Svante Arrhenius väg 16, SE-106 91 Stockholm, Sweden.

\begin{abstract}
Cobaloximes are popular $\mathrm{H}_{2}$ evolution molecular catalysts, but have so far mainly been studied in non-aqueous conditions. We show here that they are also valuable for the design of artificial hydrogenases for application in neutral aqueous solutions and report on the preparation of two well-defined biohybrid species via the binding of two cobaloxime moieties $\left\{\mathrm{Co}(\mathrm{dmgH})_{2}\right\}$ and $\left\{\mathrm{Co}\left(\mathrm{dmgBF}_{2}\right)_{2}\right\}\left(\mathrm{dmgH}_{2}=\right.$ dimethylglyoxime $)$ to apo Sperm-whale myoglobin $(\mathrm{Sw} \mathrm{Mb})$. All spectroscopic data confirm that the cobaloxime moieties are inserted within the binding pocket of the $S w \mathrm{Mb}$ protein and are coordinated to a histidine residue in axial position of the cobalt complex, resulting in thermodynamically stable complexes. QC/MM docking calculations indicated coordination preference for His93 over the other histidine residue (His64) present in the vicinity. Interestingly, the redox activity of the cobalt centers is retained in both biohybrids which provides them with catalytic activity for $\mathrm{H}_{2}$ evolution in near neutral aqueous conditions.
\end{abstract}




\section{INTRODUCTION}

Hydrogenases catalyze the reversible reduction of protons into molecular hydrogen. They function at thermodynamic equilibrium ${ }^{1}$ and display very high turnover frequencies ${ }^{2}$ thereby making them competitive as unique efficient molecular catalysts with respect to platinum metal for $\mathrm{H}_{2} / \mathrm{H}^{+}$ interconversion. ${ }^{3}$ Since their active sites contain only earth-abundant first-row transition metals, such as iron and nickel, a number of biomimetic ${ }^{4-6}$ and bioinspired ${ }^{7-10}$ synthetic catalysts for $\mathrm{H}_{2}$ evolution have been reported over the last two decades. In particular cobaloximes ${ }^{11-14}$ (Figure 1) and diimine-dioxime cobalt complexes ${ }^{15-18}$ have proved to be among the most active $\mathrm{H}_{2}$-evolving catalysts in non-aqueous media.

Few studies have addressed the activity of this class of catalysts in fully aqueous conditions. ${ }^{18-24}$ In general it seems that molecular cobalt-based catalysts such as cobaloximes or diimine-dioxime cobalt complexes are not very active at $\mathrm{pH} 7$ and we have recently shown that they get converted into cobalt-based nanoparticles during turn-over in phosphate aqueous buffer at $\mathrm{pH} 7{ }^{25}$ A possible route to the stabilization of these catalysts for applications in neutral aqueous media is through a better control of the immediate environment of the active center. Inspiration has come recently from metalloproteins in the form of so-called artificial enzymes. ${ }^{6,26-29}$ Indeed, in metalloenzymes, the polypeptidic framework controls solvent accessibility and provides the active site with a surrounding of low permittivity and polarity, thus both tuning its catalytic activity and protecting it against undesired decomposition reactions. ${ }^{30}$ Artificial enzymes, in which a molecular synthetic catalyst is embedded into a well-chosen peptide or protein, have recently proved catalytically active in water. ${ }^{6,30}$ Interestingly, the hydrophobic self-assembly of $\left[\mathrm{Co}(\mathrm{dmgH})_{2}(\mathrm{py}) \mathrm{Cl}\right]$ with photosystem I yields a hybrid complex capable of photo-driven $\mathrm{H}_{2}$ production. ${ }^{31}$

These promising results led us to construct artificial hydrogenases based on cobaloximes, namely the difluoroboryl-annulated cobaloxime $\left[\mathrm{Co}\left(\mathrm{dmgBF}_{2}\right)_{2}\left(\mathrm{H}_{2} \mathrm{O}\right)_{2}\right]\left(\mathbf{1}\right.$, Figure $1, \mathrm{dmgH}_{2}=$ dimethylglyoxime) and the proton-bridged cobaloxime $\left[\mathrm{Co}(\mathrm{dmgH})_{2}\left(\mathrm{OH}_{2}\right)_{2}\right]$ (2, Figure 1). Spermwhale myoglobin $(S w \mathrm{Mb}$, Figure 1) was chosen as the host protein because of its capability to bind several square planar complexes ${ }^{32-36}$ (including its natural cofactor, hemin) through coordination, in the axial position, of the metal ion to a histidine residue (His93) appropriately located in its hydrophobic cavity. ${ }^{32,33,37} \mathrm{We}$ report here on the preparation as well as the biochemical and spectroscopic characterization of two cobaloxime-SwMb biohybrids $S w \mathrm{Mb} \cdot \mathbf{1}$ and $\mathrm{Sw} \mathrm{Mb} \cdot \mathbf{2}$ capable of catalytic hydrogen evolution. 


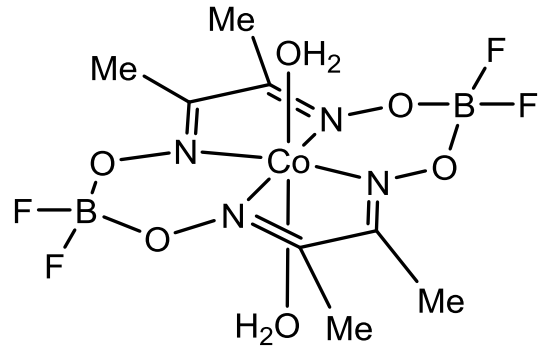



2

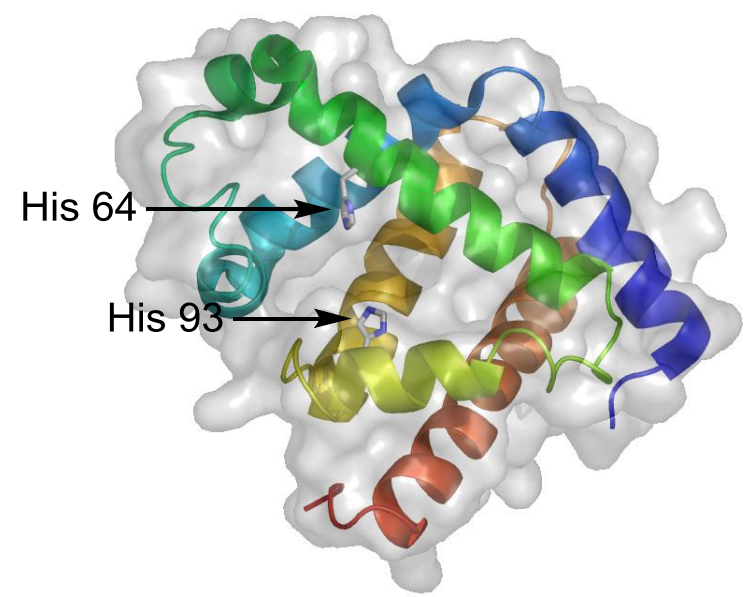

apo-SwMb

Figure 1. Molecular structure of the cobaloximes $\mathbf{1}$ and $\mathbf{2}$ and representation of apo-SwMb (PDB code 1UPD) showing both histidine residues present in its binding pocket. 


\section{EXPERIMENTAL SECTION}

Materials. Hemin, $\mathrm{EuCl}_{2}$, ethylene glycol-bis(2-aminoethylether)-N,N,N',N'-tetraacetic acid (EGTA) and Nafion ${ }^{\circledR}$ solution (5\% in ethanol) were purchased from Sigma-Aldrich. $\left[\mathrm{Co}(\mathrm{dmgH})_{2}\left(\mathrm{H}_{2} \mathrm{O}\right)_{2}\right],{ }^{38} \quad\left[\mathrm{Co}\left(\mathrm{dmgBF}_{2}\right)_{2}\left(\mathrm{H}_{2} \mathrm{O}\right)_{2}\right],{ }^{39} \quad\left[\mathrm{Ru}(\text { bipy })_{3}\right] \mathrm{Cl}_{2}{ }^{40}$ and 5-deazaflavin ${ }^{41}$ were prepared according to reported procedures. Commercial grade C100 Multi-walled Carbon Nanotubes (MWCNTs, > $95 \%$ ) were obtained from Nanocyl. S-(2,2,5,5-tetramethyl-2,5-dihydro1H-pyrrol-3-yl)methyl methanesulfonothioate (MTSL) was purchased from Reanal Private Ltd. (Budapest, Hungary).

The production in E. coli and purification of recombinant Sperm-whale myoglobin $(S w \mathrm{Mb})$ were performed according to a reported procedure with some modifications. ${ }^{42}$ In this procedure, apo$S w \mathrm{Mb}$ was obtained from resolubilisation of inclusion bodies in $0.1 \%$ trifluoroacetic acid aqueous solutions followed by two successive dialyses against 20 mmol. $\mathrm{L}^{-1}$ Tris-acetate $\mathrm{pH} 5.0$ and 50 mmol. $\mathrm{L}^{-1}$ Tris- $\mathrm{HCl}$ pH 7.5 solutions (precipitated proteins were eliminated through centrifugation at each step). Further purification was performed through gel filtration (size-exclusion chromatography) using a Superdex 75 Hiload 16/60 Prepgrade column equilibrated with 50 mmol. $\mathrm{L}^{-1}$ Tris- $\mathrm{HCl}$ pH 8.0, 20 mmol.L $\mathrm{L}^{-1} \mathrm{NaCl}$ buffer. UV-visible monitored titration confirmed that the purified protein was fully reconstituted with one equivalent of hemin.

Physical measurements. UV-Vis spectra were recorded with a Shimadzu UV-1800 spectrophotometer in quartz or plastic cells $(1 \mathrm{~cm}$ optic pathway). Circular Dichroism measurements were obtained using a Jasco J-810 spectrometer. ICP-MS cobalt titration was performed at the Department of Biochemistry, Toxicology and Pharmacology of the Centre Hospitalier Universitaire de Grenoble. ICP-AES cobalt titration was performed at the Argonne National Laboratory on a Thermo Scientific iCAP 600 spectrometer with errors within 5\%. Protein concentrations were determined through titration with Rose Bengal (using Bovin Serum Albumin as a standard). ${ }^{43}$

Continuous wave $(\mathrm{CW}) \mathrm{X}$-band $(9 \mathrm{GHz})$ EPR experiments were obtained with two distinct instruments: (i) a Bruker EMX spectrometer equipped with an Oxford ESR 910 cryostat for low temperature studies. The microwave frequency was measured with a frequency counter and the magnetic field with an NMR gaussmeter; and (ii) a Bruker ELEXSYS E580 EPR spectrometer (Bruker Biospin, Rheinstetten, Germany), equipped with a TE102 rectangular EPR resonator (Bruker ER 4102st) and a helium gas-flow cryostat (Air Product, Allentown, PA). The temperature was controlled by a Lakeshore cryogenic temperature controller (Westerville, $\mathrm{OH}$ ), 
and was about $5 \mathrm{~K}$ or $80 \mathrm{~K}$. The field modulation used in the $\mathrm{CW}$ experiments led to a derivative type lineshape. High frequency EPR measurements were performed at Argonne National Laboratory on a home-built D-band $(130 \mathrm{GHz})$ spectrometer equipped with a single mode $\mathrm{TE}_{011}$ cylindrical cavity. ${ }^{44}$ High frequency EPR spectra of the samples were recorded in pulse mode in order to remove the microwave phase distortion due to fast-passage effects. The absorption line shape of the EPR spectra was recorded by monitoring the electron spin echo (ESE) intensity from a two microwave pulse sequence as a function of magnetic field. The duration of the microwave pulses was $50 \mathrm{~ns}$ and $70 \mathrm{~ns}$, and typical separation times between microwave pulses were 150-300 ns.

Data processing was done using Xepr (Bruker BioSpin, Rheinstetten) and the Matlab ${ }^{\mathrm{TM}} 7.11 .1$ (MathWorks) environment. The magnetic parameters were obtained from theoretical simulation of the EPR spectra. The simulations were performed using the EasySpin software package (version 4.0.0). ${ }^{45}$ The accuracy in the determination of the electronic g-tensor for the set of multifrequency EPR spectra was estimated to be \pm 0.001 (relative). Note that the absolute error, depending on the calibration of the magnetic field at the sample position, is larger.

Biohybrid solutions for EPR measurements were prepared in 50 mmol. $\mathrm{L}^{-1}$ Tris- $\mathrm{HCl} \mathrm{pH}$ 7.0, added with 100 mmol. $\mathrm{L}^{-1} \mathrm{NaCl}$ with $10 \%$ glycerol and introduced in the glove-box in $4 \mathrm{~mm}$ o.d. quartz tubes. Spin quantification was performed by comparison of integral intensities from spectra recorded under non-saturating conditions with those of spectra of solutions of MTSL spin label also recorded under non-saturating conditions.

Cobalt K-edge (7.709 keV) X-ray absorption near edge structure (XANES) and extended X-ray absorption fine structure (EXAFS) spectra were collected at the beamline 12BM at the Advanced Photon Source of Argonne National Laboratory. Si (111) doubt crystals were used in the monochromator. A Pt-coated mirror was used to focus the beam and to remove higher harmonic $\mathrm{X}$-ray photons. The beam size at the sample was approximately $0.4 \mathrm{~mm}(\mathrm{v}) \mathrm{x} 1 \mathrm{~mm}(\mathrm{~h})$. A feedback system was used to control the monochromator crystal angle and was set to $70 \%$ detuning. A thirteen-element germanium solid state detector (Canberra) was used to collect iron X-ray fluorescence signals. An iron filter was placed in front of the detector for attenuation of elastic scatterings, which increased the signal ratio between the fluorescence and the elastic scattering of the sample from $<1: 100$ to $\sim 1: 1$. The outputs from the amplifiers of the detector were connected to an array of single channel analyzers (SCA) with upper and lower thresholds set to allow only $\mathrm{K}_{\alpha 1}$ and $\mathrm{K}_{\alpha 2}$ fluorescence signals to be further processed. An ion chamber was placed before the 
sample for the incident X-ray flux reference signal $\mathrm{I}_{0}$, and the second and the third ion chambers were placed after the sample. A cobalt foil inserted between the second and the third ion chambers was used for the energy calibration. The output signals from the SCA's were connected to a scalar array which interfaced with a computer hosting a data acquisition program (G. Jennings, Argonne National Laboratory). A Tris- $\mathrm{HCl}$ buffer and glycerol (10\%) mixture was used to prevent ice crystal formation for the XAS measurements at 20K. Complex 1 was measured in acetonitrile solution and the sample solution was studied inside a cryostat (Janis Model CCS-150) at 20 K.

All electrochemical measurements were carried out under nitrogen at room temperature. A standard three-electrode configuration was used consisting of a CNT-based working electrode (see below), an auxiliary platinum wire and an $\mathrm{Ag} / \mathrm{AgCl} /$ aqueous $\mathrm{AgCl}_{\text {sat }}+\mathrm{KCl} 3$ mol. $\mathrm{L}^{-1}$ (denoted as $\mathrm{Ag} / \mathrm{AgCl}$ throughout this text) reference electrode closed by a Vycor frit and dipped directly into the solution. The $\left[\mathrm{Fe}(\mathrm{CN})_{6}\right]^{3-} /\left[\mathrm{Fe}(\mathrm{CN})_{6}\right]^{4-}$ couple $\left(\mathrm{E}^{0}=0.215 \mathrm{~V}\right.$ vs $\mathrm{Ag} / \mathrm{AgCl}$ or $0.425 \mathrm{~V}$ vs $\mathrm{SHE}$ in phosphate buffer at $\mathrm{pH}=7$ ) was then used for the standardisation of the measurements in aqueous solution. ${ }^{46}$ The $\mathrm{Fc}^{+} / \mathrm{Fc}$ couple $\left(\mathrm{E}^{0}=0.45 \mathrm{~V}\right.$ vs. $\left.\mathrm{Ag} / \mathrm{AgCl}\right)$ was used as a reference when a 0.1 mol. $\mathrm{L}^{-1} \mathrm{nBu}_{4} \mathrm{NBF}_{4} \mathrm{CH}_{3} \mathrm{CN}$ solution was used as the electrolyte. Cyclic voltammograms were recorded with a Bio-logic SP300 potentiostat. Hydrogen evolution was quantified with a microClark $\mathrm{H}_{2}$-MR sensor connected to a microsensor monometer from Unisense, calibrated with $100 \%, 40 \%$ and $10 \% \mathrm{H}_{2}$ saturated deionized water. Irradiation was performed with a $300 \mathrm{~W}$ xenon lamp (Oriel, ozone free) operated at $280 \mathrm{~W}$ coupled with a water-filled Spectra-Physics 6123NS liquid filter for elimination of IR radiations, and, for the experiments using a Ru-based photosensitizer, a Spectra-Physics 59472 UV cut-off filter $(\lambda>400 \mathrm{~nm})$.

Theoretical calculations. Calculations of the isolated cobalt complexes were done with a quantum chemical (QC) density functional theory (DFT) approach using the B3LYP functional ${ }^{47-}$ ${ }^{49}$ and a triple-zeta def2-TZVP basis set. ${ }^{50}$ The ORCA program package was employed for all electronic structure calculations. ${ }^{51}$ All geometry optimizations were performed with an implicit solvent model appropriate to acetonitrile using the COSMO method. ${ }^{52,53}$

Docking calculations were carried out with a mixture of molecular mechanical (MM) and hybrid QC/MM potentials using the pDynamo modeling program. ${ }^{54}$ Starting structures for the proteins were taken from the protein data bank ( $S w \mathrm{Mb}$ PDB code $1 \mathrm{UPD})$ with all non-protein groups removed and protonation states for the appropriate residues assigned using ProPKA. ${ }^{55}$ The structures of the cobalt complexes were obtained from the previously performed DFT calculations. Initial structures for the docking were obtained by placing the cobalt complexes in the sites 
vacated by the protein prosthetic group with a cobalt-histidine nitrogen distance of $2.5 \AA$. These initial structures were then energy minimized using a mix of geometry optimization and molecular dynamics simulation with the OPLS-AA MM force field. ${ }^{56}$ The atoms of all residues within $5 \AA$ of the complex were left free to move in the simulations whereas the atoms of protein residues further away than this were harmonically restrained to their original positions. The Co-His nitrogen distance was harmonically constrained at $2.5 \AA$. Optimizations were performed at 10 degree increments of the complex about the Co-His $\mathrm{N}$ axis and the resulting structures ranked with respect to their energy. Similar calculations were performed for the cases in which water was coordinated to the cobalt distal to the histidine with the Co-water $\mathrm{O}$ distance harmonically constrained at $1.9 \AA$ A QC/MM calculations of the lowest-energy MM-optimized structures were then performed using the semi-empirical PM6 method ${ }^{57}$ and the same OPLS-AA force field as above. The QC region contained the cobalt complex, the side chain of the coordinating histidine (the $\mathrm{CH} 2$-imidazole group) and, if present, the water. Optimizations using this potential were carried out in the same way as the MM optimizations but without the harmonic constraints between the cobalt and the coordinating histidine and water groups as these interactions are now treated at the QC level of theory.

Preparation of the biohybrid $\boldsymbol{S w} \mathbf{M b} \cdot 1$. The biohybrid was prepared in a glove box under wet $\mathrm{N}_{2}$ atmosphere at $18^{\circ} \mathrm{C}$. A solution of $1\left(500 \mu \mathrm{L}, 1 \mathrm{mmol} . \mathrm{L}^{-1}\right)$ in $50 \mathrm{mmol} . \mathrm{L}^{-1}$ Tris- $\mathrm{HCl} \mathrm{pH} 7.0$ was slowly added to a solution of $S w \mathrm{Mb}\left(500 \mu \mathrm{L}, 1.7 \mathrm{mg} \cdot \mathrm{mL}^{-1}\right.$ or $\left.0.1 \mathrm{mmol} . \mathrm{L}^{-1}\right)$. The yellow solution was stirred for $1 \mathrm{~h}$ at $4^{\circ} \mathrm{C}$ and transferred to a NAP10 desalting column and eluted with the same buffer. The yellow protein fraction was collected $\left(1 \mathrm{~mL}, 0.76 \mathrm{mg} \cdot \mathrm{mL}^{-1}\right.$ or $0.45 \mathrm{mmol} . \mathrm{L}^{-1} ; 90 \%$ yield) and kept under inert atmosphere throughout the study, unless otherwise stated.

Preparation of the biohybrid $S \boldsymbol{w} \mathbf{M b} \cdot 2$. The biohybrid was prepared in a glove box under wet $\mathrm{N}_{2}$ atmosphere at $18^{\circ} \mathrm{C}$. A solution of $2\left(500 \mu \mathrm{L}, 1 \mathrm{mmol} . \mathrm{L}^{-1}\right)$ in $50 \mathrm{mmol} . \mathrm{L}^{-1}$ Tris- $\mathrm{HCl} \mathrm{pH} 7.0$ was slowly added to a solution of $S w \mathrm{Mb}\left(500 \mu \mathrm{L}, 3.6 \mathrm{mg} \cdot \mathrm{mL}^{-1}\right.$ or $\left.0.2 \mathrm{mmol} . \mathrm{L}^{-1}\right)$. The yellow solution was stirred for $1 \mathrm{~h}$ at $4^{\circ} \mathrm{C}$, transferred to a NAP10 desalting column and eluted with the same buffer. The yellow protein fraction was collected $\left(1 \mathrm{~mL}, 1.2 \mathrm{mg} \cdot \mathrm{mL}^{-1}\right.$ or $0.7 \mathrm{mmol.L}{ }^{-1} ; 66 \%$ yield) and kept under inert atmosphere throughout the study, unless otherwise stated.

Preparation of modified CNT electrodes. A suspension of MWCNTs (29 mg) in absolute EtOH $(210 \mathrm{~mL})$ was homogeneized through sonication. Aliquots of $10 \mu \mathrm{L}$ were successively deposited onto a Teflon-embedded glassy carbon electrode $(5 \mathrm{~mm}$ o.d.) until the electroactive surface was totally covered. The electrode was dried in air and then a drop $(15 \mu \mathrm{L})$ of the proteic solution was 
deposited on the surface of the MWCNTs. A Nafion solution (15 $\mu \mathrm{L})$ was eventually added after drying in air.

Catalytic assays with $\mathrm{Eu}(\mathrm{II})$ salts. The preparation was done in a glove-box under wet $\mathrm{N}_{2}$ atmosphere at $18^{\circ} \mathrm{C}$. A solution of $\left[\mathrm{Eu}(\mathrm{EGTA})\left(\mathrm{H}_{2} \mathrm{O}\right)\right]^{2-}\left(200 \mathrm{mmol} \cdot \mathrm{L}^{-1}\right)$ in $1 \mathrm{~mol} . \mathrm{L}^{-1}$ Tris- $\mathrm{HCl} \mathrm{pH}$ 8.0 buffer was prepared from equivalent volumes of stock solutions $\left(400 \mathrm{mmol} . \mathrm{L}^{-1}\right)$ of $\mathrm{EuCl}_{2}$ and EGTA. Solutions of biohybrids $(S w \mathrm{Mb} \cdot \mathbf{1}$ or $S w \mathrm{Mb} \cdot 2)$ were prepared in situ from a solution of $S w \mathrm{Mb}$ (typically $100 \mu \mathrm{L}, 0.1 \mathrm{mmol} . \mathrm{L}^{-1}$ ) in $50 \mathrm{mmol} . \mathrm{L}^{-1}$ Tris- $\mathrm{HCl} \mathrm{pH} 7.0$ buffer and a solution of $\mathbf{1}$ or $\mathbf{2}\left(10 \mu \mathrm{L}, 0.8 \mathrm{mmol} . \mathrm{L}^{-1}\right)$ in deionized water; $\mathbf{1}$ or $\mathbf{2}$ are purposely introduced slightly substoichiometrically to ensure complete binding to the protein. This solution was transferred into Unisense $400 \mu \mathrm{L}$ MicroRespiration Chambers, taken out of the glove-box and the $\mathrm{H}_{2}$ microsensor was plunged in the solution. Once the signal stabilized for $10 \mathrm{~min}$, the Eu(II) solution was added via a Hamilton syringe.

Photocatalytic assays. The preparation was done in a glove-box under wet $\mathrm{N}_{2}$ atmosphere at $18^{\circ} \mathrm{C}$. Solutions of $\left[\mathrm{Ru}(\text { bipy })_{3}\right] \mathrm{Cl}_{2}\left(10 \mathrm{mmol} . \mathrm{L}^{-1}\right)$ and deazaflavin $\left(1.4 \mathrm{mmol} . \mathrm{L}^{-1} ; \varepsilon_{400 \mathrm{~nm}}=12000\right.$ $\left.\mathrm{mol}^{-1} \cdot \mathrm{L} . \mathrm{cm}^{-1}\right)$ were prepared in deionized water. Solutions of biohybrids $(S w \mathrm{Mb} \cdot \mathbf{1}$ or $S w \mathrm{Mb} \cdot \mathbf{2})$ were prepared in situ from a solution of $S w \mathrm{Mb}$ (typically $100 \mu \mathrm{L}, 0.1 \mathrm{mmol} . \mathrm{L}^{-1}$ ) in $50 \mathrm{mmol} . \mathrm{L}^{-1}$ Tris-HCl pH 7.0 buffer and a solution of $\mathbf{1}$ or $\mathbf{2}\left(10 \mu \mathrm{L}, 0.8 \mathrm{mmol} . \mathrm{L}^{-1}\right)$ in deionized water; 1 or 2 were purposely introduced slightly substoichiometrically to ensure complete binding to the protein.

In experiments based on $\left[\mathrm{Ru}(\text { bipy })_{3}\right] \mathrm{Cl}_{2}$ as the photosensitizer, the biohybrid solution was diluted with 50 mmol. $\mathrm{L}^{-1}$ potassium phosphate $\mathrm{pH} 6$ buffer complemented with $\mathrm{NaCl}\left(150 \mathrm{mmol} . \mathrm{L}^{-1}\right)$ and sodium ascorbate $\left(100 \mathrm{mmol} \cdot \mathrm{L}^{-1}\right)$. The solution was then transferred into Unisense $400 \mu \mathrm{L}$ MicroRespiration Chambers, taken out of the glove-box and the $\mathrm{H}_{2}$ microsensor was plunged in the solution. Once the signal stabilized for $10 \mathrm{~min}$, the $\left[\mathrm{Ru}(\text { bipy })_{3}\right] \mathrm{Cl}_{2}$ solution (20 equivalents with regards to the cobalt catalyst) was added via a Hamilton syringe and irradiation started.

In experiments based on deazaflavin as the photosensitizer, the biohybrid solution was diluted with 50 mmol. $\mathrm{L}^{-1}$ Tris-HCl buffer $\mathrm{pH}$ 7.0. The solution was then transferred into Unisense $400 \mu \mathrm{L}$ MicroRespiration Chambers, taken out of the glove-box and the $\mathrm{H}_{2}$ microsensor was plunged in the solution. Once the signal stabilized for $10 \mathrm{~min}$, the deazaflavin solution ( 0.5 equivalents with regards to the cobalt catalyst) was added via a Hamilton syringe and irradiation started. 


\section{RESULTS}

\section{Preparation and biochemical characterization of biohybrids}

Reaction of apo-SwMb (10-100 $\mu$ mol. $\mathrm{L}^{-1}$ in Tris-HCl buffer, $\left.\mathrm{pH} 7.0\right)$ with 5-10 molar equivalents of the cobaloximes 1 or $\mathbf{2}$ yielded the biohybrids $S w \mathrm{Mb} \cdot \mathbf{1}$ and $S w \mathrm{Mb} \cdot \mathbf{2}$. Excess of cobaloxime was removed using size-exclusion chromatography. Quantitative analysis of cobalt (ICP-MS or ICPAES) and protein (Rose Bengal method) indicated the presence of one cobalt complex per polypeptide chain. Concentration through centrifugation on membranes with $3 \mathrm{kDa}$ cut-off was limited as it generally resulted in a loss of cobalt complex (approximatively 30\% and 60\% for preparing solutions with 1 and 2 mmol. $\mathrm{L}^{-1}$ final protein concentration respectively). Calibrated size-exclusion gel chromatography confirmed the monomeric nature of the biohybrids, which coelute with apo- and holo- $S w \mathrm{Mb}$ proteins.

\section{UV-visible spectroscopy}

The UV-visible spectra of solutions of $S w \mathrm{Mb} \cdot \mathbf{1}$ and $S w \mathrm{Mb} \cdot \mathbf{2}$ are shown in Figure 2 and $\mathrm{S} 1$, respectively, together with those of apo-Sw Mb and complexes $\mathbf{1}$ and $\mathbf{2}$ at the same concentration. The spectrum of $S w \mathrm{Mb} \cdot \mathbf{1}$ shows features of the spectra of its two components: i) a band in the 280 $\mathrm{nm}$ region characteristic of the protein, ii) a band at $260 \mathrm{~nm}$ present in the spectrum of 1 and iii) a broad and flat absorption band between 350 and $450 \mathrm{~nm}$, related to the two absorption features of complex $1\left(327 \mathrm{~nm}, \varepsilon=1.710^{3} \mathrm{~mol}^{-1} . \mathrm{L} . \mathrm{cm}^{-1}\right.$ and $\left.455 \mathrm{~nm}, \varepsilon=310^{3} \mathrm{~mol}^{-1} . \mathrm{L} . \mathrm{cm}^{-1}\right)$ that are due to $\mathrm{d}-\mathrm{d}$ transitions in the $\mathrm{Co}(\mathrm{II})$ center. ${ }^{58}$ The blue-shift and the broadening of these bands are caused not only by the polypeptide environment but also by coordination of His 93 as histidine ligand is a strongerligand than water. Figure S2 underlines that these bands are similarly affected when $\mathbf{1}$ is treated with increasing concentrations of imidazole. By contrast, the UV-visible spectrum of $S w \mathrm{Mb} \cdot 2$ lacks the specific absorption band expected for a Co(II) center. ${ }^{58}$ Instead an important shoulder is observed in the 300-400 region in addition to the absorption band of the protein at 280 $\mathrm{nm}$. This shoulder is reminiscent of the absorption of $\mathrm{Co}(\mathrm{III})$ cobaloximes such as [Co(gh $\left.)_{2} \mathrm{pyCl}\right]$ ( $\mathrm{gH}_{2}=$ glyoxime, Figure $\left.\mathrm{S} 1\right)$. 


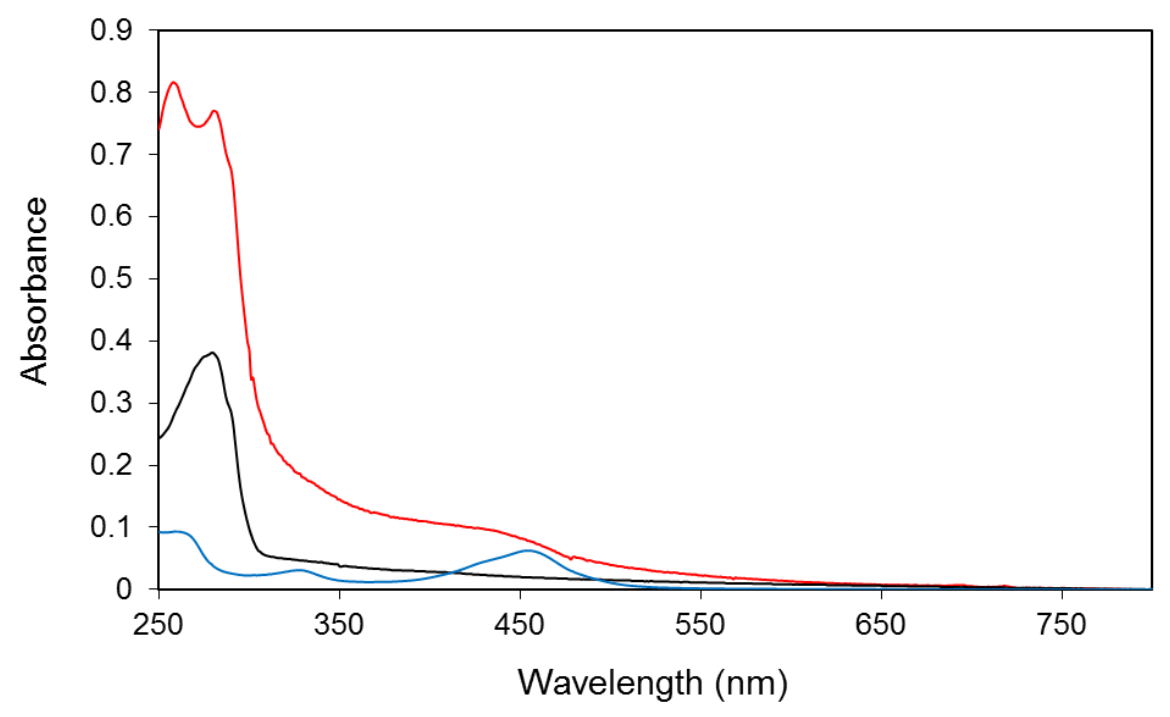

Figure 2. UV-visible spectra of $30 \mu \mathrm{mol} . \mathrm{L}^{-\mathbf{1}}$ solutions of apo-Sw Mb (black trace), $\mathbf{1}$ (blue trace) and $S w \mathrm{Mb} \cdot \mathbf{1}$ (red trace) in $50 \mathrm{mmol} . \mathrm{L}^{-1}$ Tris- $\mathrm{HCl} \mathrm{pH}$ 7.5.

We investigated the possibility of replacing $\mathbf{1}$ and $\mathbf{2}$ by hemin in $S w \mathrm{Mb} \cdot \mathbf{1}$ and $S w \mathrm{Mb} \cdot \mathbf{2}$, a strategy previously used by Watanabe and coworkers to assess the presence of Schiff-base complexes within $S w \mathrm{Mb}$ cavity. ${ }^{33}$ When apo-Sw Mb $\left(10 \mu \mathrm{mol} . \mathrm{L}^{-1}\right)$ was treated with 1 equiv. of hemin at room temperature, holo- $S w \mathrm{Mb}$ formed within a few minutes. Conversely, no hemin could be incorporated into $S w \mathrm{Mb} \cdot \mathbf{1}$ or $S w \mathrm{Mb} \cdot \mathbf{2}$ under the same conditions, as shown by UV-Vis spectroscopy (Figure 3 and S3). This observation further supports the hypothesis that the cobaloximes occupy the hemin-binding site. 


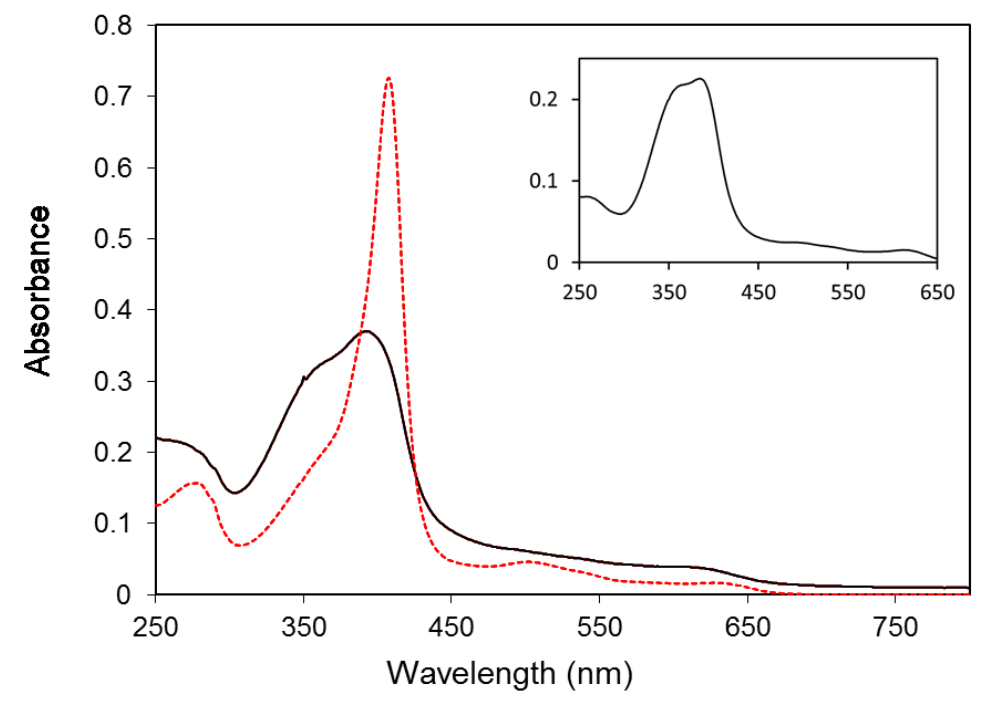

Figure 3. UV-visible spectra of $10 \mu \mathrm{mol} . \mathrm{L}^{-1}$ solutions $\left(50 \mathrm{mmol} . \mathrm{L}^{-1}\right.$ Tris- $\left.\mathrm{HCl} \mathrm{pH} 7.5\right)$ of $S w \mathrm{Mb} \cdot \mathbf{1}$ reacted for $4 \mathrm{~h}$ with 1 equiv. hemin (black trace) and holo- $S w \mathrm{Mb}$ (red dotted trace); the spectrum of the free hemin $\left(10 \mu \mathrm{mol} . \mathrm{L}^{-1}\right)$ under similar conditions is shown in the inset.

\section{Circular dichroism}

Figure 4 compares the circular dichroism spectrum of $S w \mathrm{Mb} \cdot 2$ in the UV region with those of apo- and holo- $S w \mathrm{Mb}$. Similar data were obtained with $S w \mathrm{Mb} \cdot \mathbf{1}$. The spectra all show features at 205 and $225 \mathrm{~nm}$ associated with the presence of alpha helices. The signal in the 190-200 nm region in holo- $S w \mathrm{Mb}$ spectrum, absent in that of apo- $S w \mathrm{Mb}$, has been assigned to a specific local protein folding around the heme through coordination by His $93 .{ }^{5960}$ The same signal is observed in the spectra of both biohybrids, further supporting the hypothesis that the Co complexes are coordinated by His93 in the biohybrids.

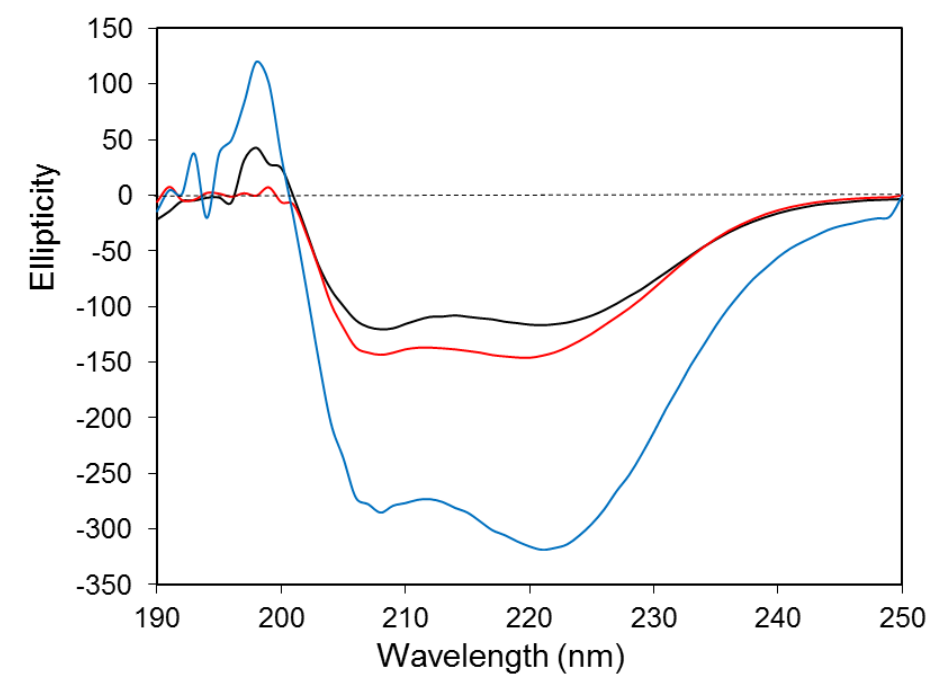


Figure 4. CD spectra of $80 \mu \mathrm{mol} . \mathrm{L}^{-1}$ solutions of $S w \mathrm{Mb} \cdot 2$ (black trace), apo-Sw $\mathrm{Mb}$ (red trace) and holo-Sw $\mathrm{Mb}$ (blue trace).

\section{EPR spectroscopy}

The EPR spectrum of a $S w \mathrm{Mb} \cdot \mathbf{1}$ solution shown in Figure 5 is typical for low-spin ( $\mathrm{S}=1 / 2) \mathrm{Co}$ (II) in cobaloximes. ${ }^{61,62}$ A basic analysis can be performed using the high field part of the spectrum. The hyperfine coupling with the ${ }^{59} \mathrm{Co}$ nucleus ( $\mathrm{I}=7 / 2 ; 100 \%$ natural abundance) results in the splitting of the $g_{z}$ component into eight signals, six of which are easily distinguishable in the high field region. Each of these signals exhibits a three-line pattern (1.4 $\mathrm{mT}$ splitting) that indicates axial coordination by a single nitrogen atom ( $\mathrm{I}=1$; >99\% natural abundance), likely from a histidine residue. Extensive previous EPR studies of this and closely related cobaloximes in a variety of solvents have shown that cobaloximes without axial nitrogen atom or with two axial coordinating nitrogen atoms look entirely different. ${ }^{61-64}$ As an example, Figure 5 shows a spectrum of $\mathbf{1}$ in methanol, where no axial coordination by nitrogen takes place. Unbound cobaloxime in aqueous solution (Table 1) gives an EPR spectrum very similar to the one obtained in methanol. ${ }^{61}$


Figure 5. Left: Comparison of experimental (black trace) and simulated (red trace) CW X-band EPR spectrum $(9.34 \mathrm{GHz})$ of a solution of $S w \mathrm{Mb} \cdot 1\left(0.72 \mathrm{mmol}_{\mathrm{Co}} \cdot \mathrm{L}^{-1}\right.$ and $\left.1.8 \mathrm{mmol}_{S w \mathrm{Mb}} \cdot \mathrm{L}^{-1}\right)$ in frozen mixture of 50 mmol. $\mathrm{L}^{-1}$ Tris- $\mathrm{HCl}$ pH 7.0, $100 \mathrm{mmol} . \mathrm{L}^{-1} \mathrm{NaCl}$ and $10 \%$ glycerol recorded at $5 \mathrm{~K}$. Positions of the g-tensor principal components are shown by arrows. The spectrum of $\mathbf{1}$ in methanol (no axial coordination by nitrogen), shown in blue, is provided for easy comparison; Right: Electron spin echo-detected high frequency (D-band, $130 \mathrm{GHz}$ ) EPR spectra of $S w \mathrm{Mb} \cdot \mathbf{1}$; $\mathrm{T}=9 \mathrm{~K}$; absorptive lineshape. Positions of the g-tensor principal components are shown by arrows. 
Spin quantification determined the Co(II) low-spin cobaloxime mole fraction to only account for approximately $36 \%$ of the Co concentration in the sample. For comparison, spin quantification on samples of 1 in methanol (Figure 5) is in agreement with $100 \%$ of the metal content being lowspin Co(II). Broad field sweeps were performed at X-band (Figure S4) but no sign of high-spin Co(II) or other paramagnetic Co species ${ }^{65,66}$ was detected. The pulsed D-band EPR spectrum (Figure 5) showed that at least one other minor paramagnetic species was present in the sample, with a relative broad lineshape, although the identity of these minor species is unclear. The most likely reason for the difference between spin quantification and Co titration is that a significant part of the Co species is diamagnetic, most likely in Co(III) oxidation state, which is in agreement with the XANES data discussed below. The sample of the $S w \mathrm{Mb} \cdot \mathbf{2}$ biohybrid was found to be EPR-silent, which likely reflects the presence of a $\mathrm{Co}(\mathrm{III})$ cobaloxime unit, in agreement with its electronic absorption spectra (Figure S1). The EPR spectra recorded at X-band and D-band have been simulated (Figure 5), and the magnetic parameters, including principal g-values, ${ }^{59} \mathrm{Co}$ and ${ }^{14} \mathrm{~N}$ hyperfine values are given in Table 1.

Table 1. EPR simulation parameters for the $\left\{\mathrm{Co}\left(\mathrm{dmgBF}_{2}\right)_{2}\right\}$ moiety in different surroundings including $S w \mathrm{Mb} \cdot \mathbf{1}$. All parameters besides those for the $S w \mathrm{Mb} \cdot \mathbf{1}$ biohybrid have been taken from previous work. ${ }^{61}$ Note, that the signs of the hyperfine coupling constants $A_{\mathrm{x}}, A_{\mathrm{y}}$, and $A_{\mathrm{z}}$ could not be determined by analysis of the EPR spectra. Thus, only the magnitude is given. The ${ }^{14} \mathrm{~N}$ hyperfine coupling constants refer to the axial ligand.

\begin{tabular}{|c|c|c|c|c|c|}
\hline Solvent/Ligand(s)/Protein & $\mathrm{g}_{\mathrm{x}}$ & $\mathrm{g}_{\mathrm{y}}$ & $\mathrm{g}_{\mathrm{z}}$ & $\left.|\mathrm{A}|\left({ }^{59} \mathrm{Co}\right) \mathrm{MHz}\right]$ & $|\mathrm{A}|\left({ }^{14} \mathrm{~N}_{)}[\mathrm{MHz}]\right.$ \\
\hline$S w \mathrm{Mb} \cdot \mathbf{1}$ & 2.3365 & 2.1835 & 2.0010 & $80,10,292 *$ & $30,30,39 *$ \\
\hline 1 in Glycerol: $\mathrm{H}_{2} \mathrm{O}$ mixture & 2.2750 & 2.1785 & 2.0065 & $15,15,329 *$ & $\mathrm{n} / \mathrm{a}$ \\
\hline 1 in methanol & 2.2840 & 2.1820 & 2.0080 & $53,20,338 *$ & $\mathrm{n} / \mathrm{a}$ \\
\hline $\mathbf{1}+1$ equiv. pyridine in methanol & 2.2380 & 2.1530 & 2.0058 & $10,10,285^{*}$ & $33,36,43$ \\
\hline $\mathbf{1}+1$ equiv. $\mathrm{p}-\mathrm{PDI}^{\#}$ in toluene & 2.3473 & 2.1815 & 2.0000 & $85,10,306^{*}$ & $30,30,40^{*}$ \\
\hline
\end{tabular}

\footnotetext{
* In these cases, the hyperfine coupling constants $A_{\mathrm{x}}$ and $A_{\mathrm{y}}$ were estimated from the linewidth.

${ }^{\#}$ p-PDI = N-cyclohexyl-N'-4-pyridyl-1,7-dipyrrolidinylperylene-3,4:9,10-tetracarboxylic acid bisimide
} 


\section{XANES measurements}

Figure 6 displays the XANES spectra at the Co K-edge for the two biohydrids $S w \mathrm{Mb} \cdot \mathbf{1}$ and $S w \mathrm{Mb} \cdot \mathbf{2}$ together with the spectra of $\mathbf{1}$ (recorded in acetonitrile solution) and of electrochemically generated one-electron oxidized $\mathbf{1}^{+}\left(\mathrm{Co}^{\mathrm{III}}\right)$ recorded in $\mathrm{CH}_{3} \mathrm{CN}$. Comparison of the latter two shows that a significant upward edge shift would take place when $\mathrm{Co}^{\mathrm{II}}$ is oxidized to $\mathrm{Co}^{\mathrm{III}}$, as well as when the coordination geometry of the complex increases. This edge energy blue shift is visible from the spectra of $S w \mathrm{Mb} \cdot \mathbf{1}$ and $S w \mathrm{Mb} \cdot \mathbf{2}$ as compared to the spectrum of $\mathbf{1}$. However, the edge energies in the XANES spectra of $S w \mathrm{Mb} \cdot \mathbf{1}$ and $S w \mathrm{Mb} \cdot \mathbf{2}$ are still about $1 \mathrm{eV}$ lower than that of $\mathbf{1}^{+}$ $\left(\mathrm{Co}^{\mathrm{III}}\right)$. The spectrum simulated with a mixture of $\mathrm{Co}^{\mathrm{II}}(50 \pm 10 \%)$ and $\mathrm{Co}^{\mathrm{III}}(50 \pm 10 \%)$ species reproduces the features observed in $S w \mathrm{Mb} \cdot \mathbf{1}$. This result is in agreement with the EPR data suggesting that an approximately 1:1 mixture of $\mathrm{Co}^{\mathrm{II}}$ and $\mathrm{Co}^{\mathrm{III}}$ is present in the biohybrid samples.

Meanwhile, the insets of Figure 6 focusing at the pre-edge region clearly show a higher intensity of the quadrupole allowed $1 \mathrm{~s} \rightarrow 3 \mathrm{~d}_{\mathrm{x} 2-\mathrm{y} 2}$ transition in the case of the Co ${ }^{\mathrm{II}}$ complex with respect to the $\mathrm{Co}^{\mathrm{III}}$ complex. The former has two pre-edge features while the latter has only one weak feature (Figure 6B). Based on the nature of the quadrupole allowed transition(s), it can be deduced that i) $\mathrm{Co}^{\mathrm{III}}$ is most likely a low spin species with only one (or one set of) vacant $3 \mathrm{~d}$ orbital(s) and a nearly symmetric octahedral geometry, and ii) $\mathrm{Co}^{\mathrm{II}}$ coordination geometry is less symmetric with a high spin state showing at least two vacant $3 \mathrm{~d}$ orbital energy levels. The intensity of the pre-edge region is lower for the two biohybrids than for $\mathbf{1}$ (insets in Figures 6A and 6B), indicating that the coordination sphere is more symmetrical in the biohybrids. However, there is no sign of the second pre-edge feature in the low temperature data of $\mathbf{1}$, indicating that $\mathbf{1}\left(3 d^{7}\right)$ has a low spin state at $20 \mathrm{~K}$ with only one set of vacant and nearly isoenergetic $3 d$ orbitals. Such a temperature dependent spin-state formation has been commonly observed in iron species. ${ }^{67}$ The higher preedge intensity also indicates some $3 d-4 p$ mixing $^{67}$ in $\mathbf{1}$, but such a mixing is reduced in biohybrids which could be due to the fact that both $\mathrm{Co}^{\mathrm{II}}$ and $\mathrm{Co}^{\mathrm{III}}$ species gain a more symmetrical coordination sphere, most likely an octahedral geometry, when bound to the protein matrix. 

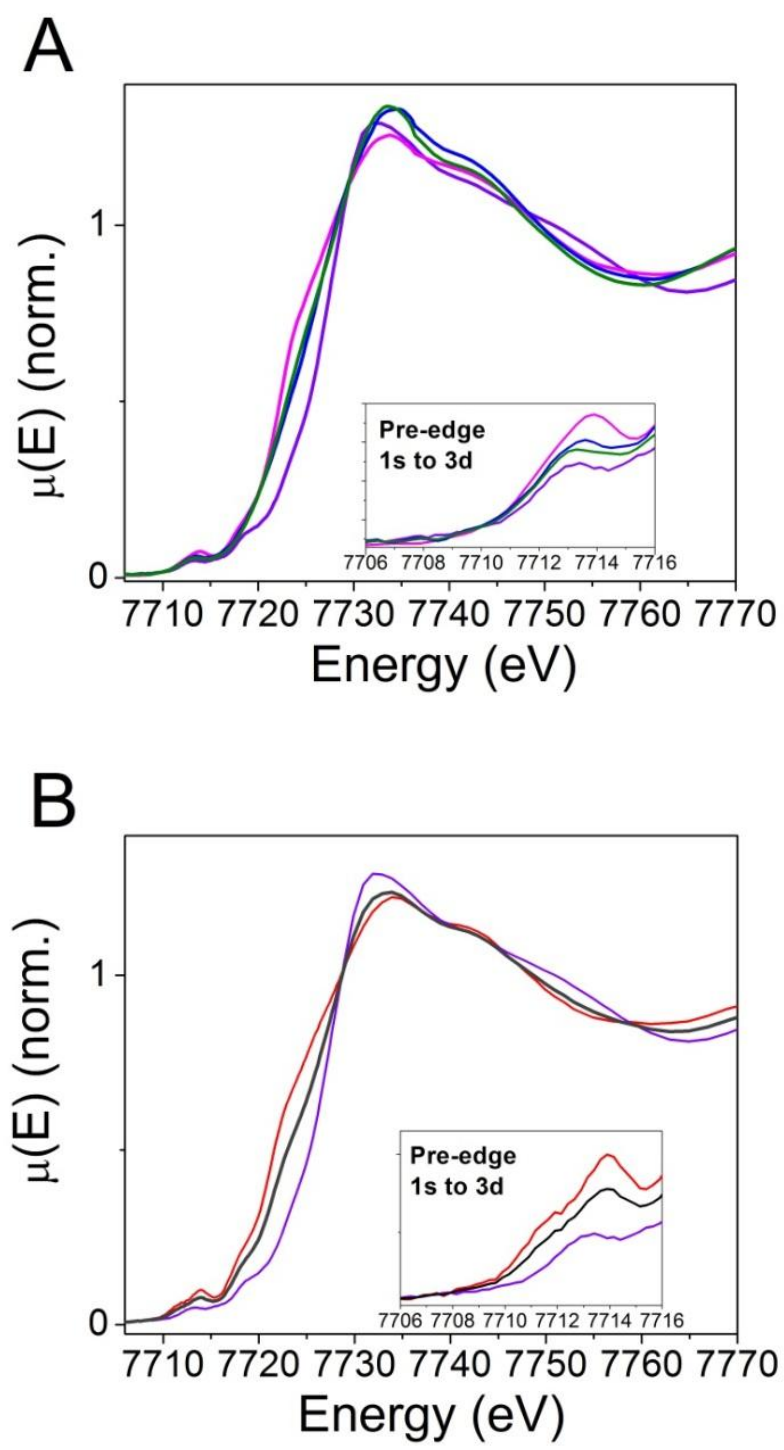

Figure 6. Co K near-edge spectra $[\mu(\mathrm{E})$, normalized absorption intensity vs. photon energy] for A) $S w \mathrm{Mb} \cdot \mathbf{1}$ (blue trace) and $S w \mathrm{Mb} \cdot \mathbf{2}$ (green trace) 1 (magenta trace, in acetonitrile) and electrochemically generated $\mathbf{1}^{+}$(purple trace) at $20 \mathrm{~K}$, and B) room-temperature spectra of $\mathrm{CH}_{3} \mathrm{CN}$ solutions of 1 in the $\mathrm{Co}^{\mathrm{II}}$ (red trace) and $\mathrm{Co}^{\mathrm{III}}$ (purple trace) states generated via electrolysis along with the simulated spectrum with an approximatively 1:1 ratio (of the two corresponding spectra (black trace).

\section{Structural studies}

\section{EXAFS}

Figure 8 shows the EXAFS and the Fourier-transformed EXAFS spectra of the two biohydrids $S w \mathrm{Mb} \cdot \mathbf{1}$ and $S w \mathrm{Mb} \cdot \mathbf{2}$ together with the spectrum of $\mathbf{1}^{68}$ The amplitude of the oscillations shown in Figure 7A indicates possible increase of the number of nearest neighboring atoms ligated to the cobalt center and/or more uniform nearest neighbor distances in the biohybrid samples compared 
to 1 . With the exception of this possible increase in cobalt coordination number, no major structural changes are observed upon insertion of $\mathbf{1}$ into SwMb in terms of distances between the Co center and the first coordinating atoms. The same information can be drawn from the Fourier transformed spectrum of 1 (Figure 7B), in which the highest peak corresponds to the nearest Co-N or Co-O distances, i.e. the four equatorial as well as one or two axial ligands. In the $S w \mathrm{Mb} \cdot \mathbf{1}$ and $S w \mathrm{Mb} \cdot \mathbf{2}$ spectra, the intensity of this peak is significantly higher than that in the spectrum of $\mathbf{1}$, indicating an increase of the coordination number (assigned to His 93, see below) and/or a better uniformity in bond distances between the cobalt center and the equatorial and axial ligands.
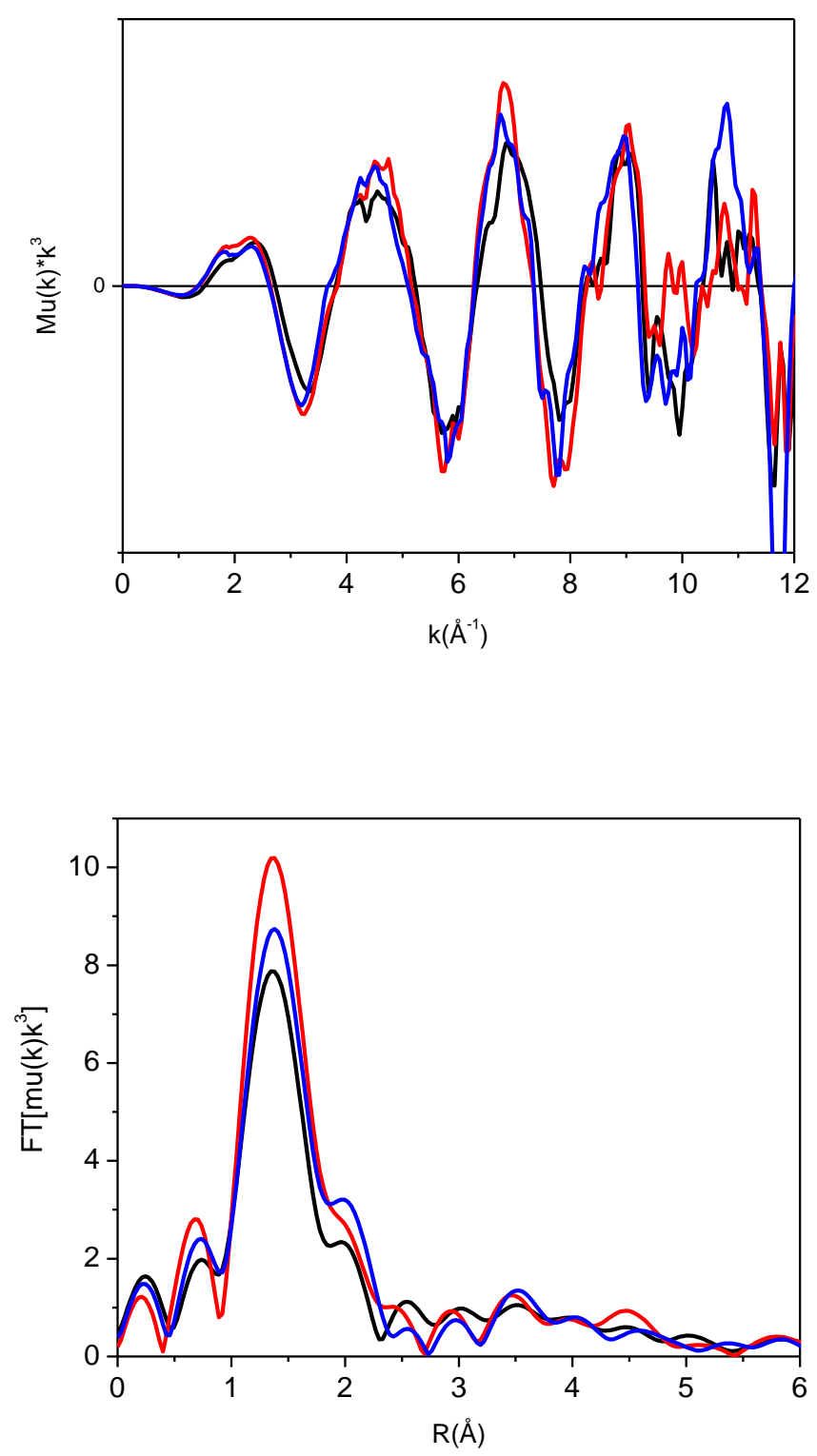

Figure 7. top: EXAFS spectra; bottom: Fourier transformed EXAFS spectra of 1 (black trace), $S w \mathrm{Mb} \cdot \mathbf{1}$ (red trace) and $S w \mathrm{Mb} \cdot \mathbf{2}$ (blue trace). 


\section{Docking}

Docking calculations were initially performed with a molecular mechanics (MM) energy function to identify the possible accommodation of the $\left\{\mathrm{Co}\left(\mathrm{dmgBF}_{2}\right)_{2}\right\}$ and $\left\{\mathrm{Co}(\mathrm{dmgH})_{2}\right\}$ moieties within the SwMb cavity. Coordination of His 93 to the Co center of both moieties was clearly more stable than coordination to the other histidine (H64) residue present in the cavity. From this model, an axial water molecule was coordinated in the trans position to His93 and the system was optimized using a quantum chemical QC/MM potential with the QC region containing the cobalt complex and the side chain of the coordinating histidine. Figure 8 displays a superposition of the optimized structures around the metallic centers in both biohybrids. Other representations of these structures are shown in Figure 9 and S5. At this level of theory, no dissociation of the axial ligands (either water or His93) was observed. In the case of $S w \mathrm{Mb} \cdot \mathbf{2}$, a hydrogen bond was established between the coordinated water molecule and His 64 (with a $\mathrm{N} \varepsilon{ }^{\cdots} \mathrm{H}$ distance of $2.02 \AA$ ). Such an interaction was not formed in the case of $S w \mathrm{Mb} \cdot \mathbf{1}$ due to the displacement of His64 out of hydrogen-bonding range by the larger complex 1 ligand. Table 2 collects optimized structural data for both biohybrids and compares them to literature values for the structurally characterized $\left[\mathrm{Co}\left(\mathrm{dpgBF}_{2}\right)_{2}\left(\mathrm{CH}_{3} \mathrm{CN}\right)_{2}\right]^{13}$ and $\left[\mathrm{Co}(\mathrm{dmgH})_{2} \mathrm{pyI}\right]^{69}$ complexes. These data fit perfectly with the conclusions drawn from the EXAFS experiments. 


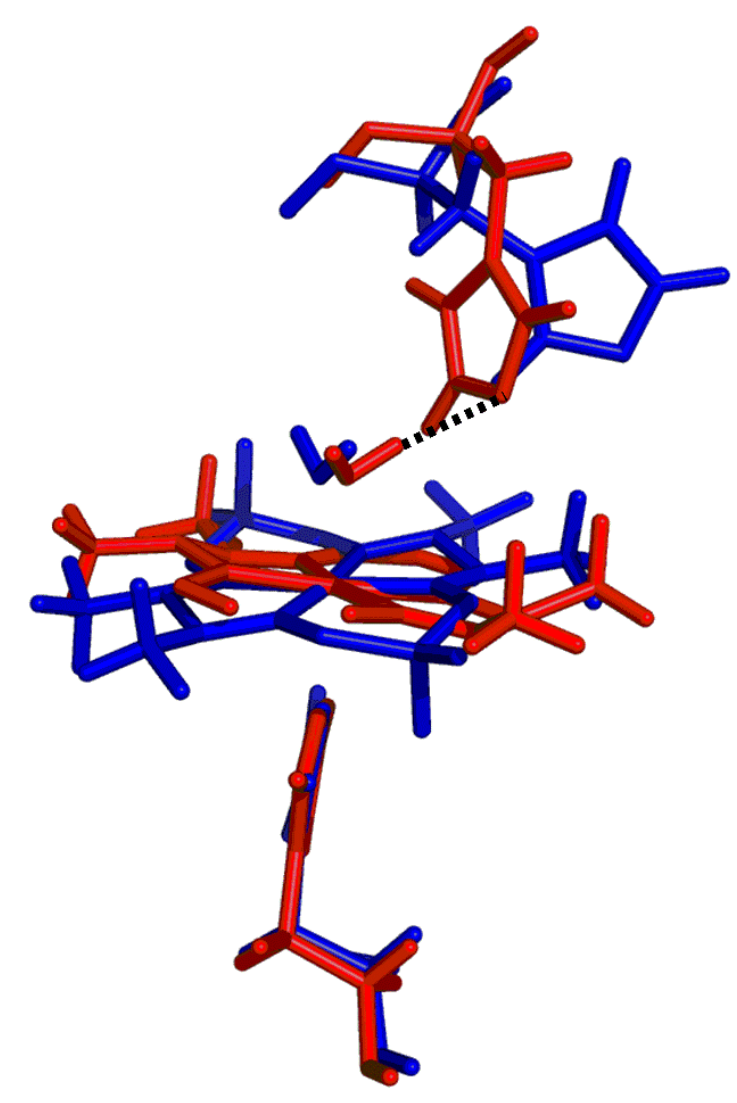

Figure 8. Superposition of the structures around the metallic centers in $S w \mathrm{Mb} \cdot \mathbf{1}$ (blue) and Sw Mb 2 (red) computed at the QC/MM level. From the polypeptide chains, only His 93 (bottom) and His 64 (top) are represented. The hydrogen bond between the Co-coordinated water molecule and His64 is shown in dashed-black in the case of $S w \mathrm{Mb} \cdot 2$.

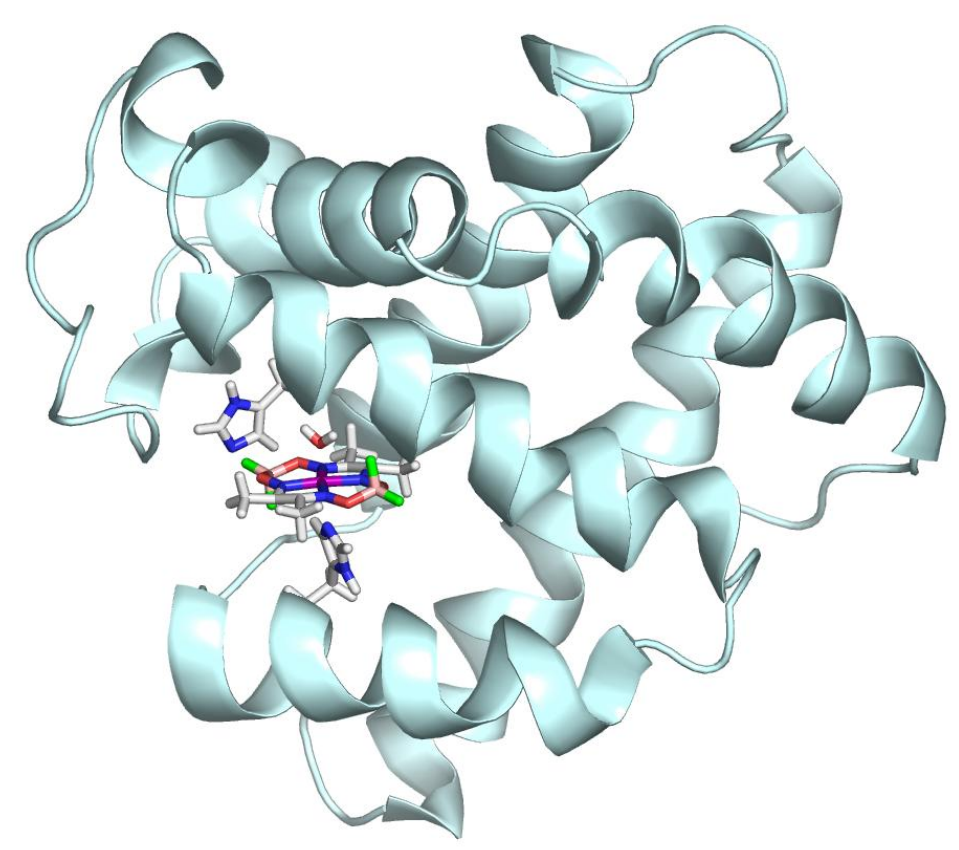




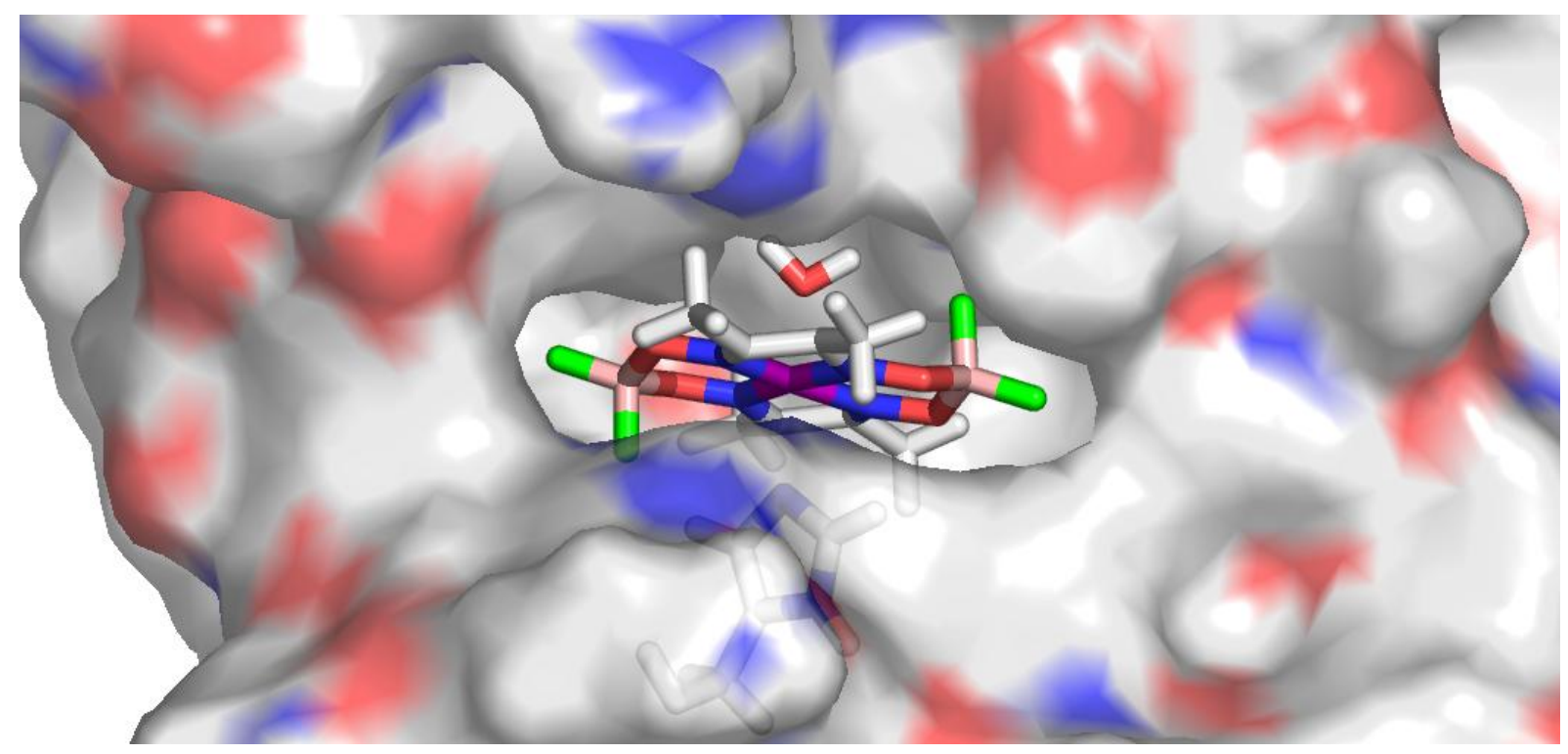

Figure 9. Top: structure of $S w \mathrm{Mb} \cdot \mathbf{1}$ as computed at the QC/MM level; bottom: electrostatic representation of the protein environment around $\mathbf{1}$ in $S w \mathrm{Mb} \cdot \mathbf{1}$ (hydrophilic regions are shown in red (oxygen atoms) and blue (nitrogen atoms) while hydrophobic regions are shown in grey. The cobalt atom is depicted in purple, boron in pink and fluorine in green.

Table 2. First neighboring atom bond lengths from simulations (docking data for $S w \mathrm{Mb} \cdot \mathbf{1}$ and $S w \mathrm{Mb} \cdot 2$ and DFT calculations with the B3LYP functional and the TZVP basis in an implicit solvent model of acetonitrile for $\left.\left[\mathrm{Co}\left(\mathrm{dmgBF}_{2}\right)_{2}\left(\mathrm{CH}_{3} \mathrm{CN}\right)\right]\right)$ and experimental (Co K-edge EXAFS) or cobaloxime X-ray structures.

\begin{tabular}{|c|c|c|c|c|}
\hline \multirow[t]{2}{*}{ Compound } & \multicolumn{3}{|c|}{ Bond lengths ( $($ ) } & \multirow{2}{*}{ Method } \\
\hline & Co-N $\left(\operatorname{His}_{\mathrm{p}}\right)$ & Co-L & $\begin{array}{l}\text { Co- } \mathrm{N}_{\mathrm{eq}} \text { (ligand) } \\
(\min / \max )\end{array}$ & \\
\hline $\begin{array}{c}1 \\
\left(\left[\mathrm{Co}\left(\mathrm{dmgBF}_{2}\right)_{2}\left(\mathrm{CH}_{3} \mathrm{CN}\right)\right]\right)\end{array}$ & - & $\begin{array}{c}2.17 \\
\left(\mathrm{~L}=\mathrm{CH}_{3} \mathrm{CN}\right)\end{array}$ & $1.90-1.91$ & DFT \\
\hline$S w \mathrm{Mb} \cdot \mathbf{1}$ & 1.97 & $2.19\left(\mathrm{~L}=\mathrm{H}_{2} \mathrm{O}\right)$ & $1.87 / 1.9$ & $\mathrm{QC} / \mathrm{MM}$ \\
\hline$S w \mathrm{Mb} \cdot \mathbf{2}$ & 1.93 & $2.23\left(\mathrm{~L}=\mathrm{H}_{2} \mathrm{O}\right)$ & $1.93 / 1.95$ & $\mathrm{QC} / \mathrm{MM}$ \\
\hline$\left.\left[\mathrm{Co}(\mathrm{dpgBF})_{2}\right)_{2}\left(\mathrm{CH}_{3} \mathrm{CN}\right)_{2}\right]$ & - & $\begin{array}{c}2.241(3) \\
\left(\mathrm{L}=\mathrm{CH}_{3} \mathrm{CN}\right)\end{array}$ & $1.882(3) / 1.889(3)$ & $\mathrm{X}$-ray ${ }^{13}$ \\
\hline$\left[\mathrm{Co}(\mathrm{dmgH})_{2} \mathrm{pyI}\right]$ & $1.982(4)$ & $2.582(1)$ & $1.887(4) / 1.900(4)$ & X-ray ${ }^{69}$ \\
\hline
\end{tabular}




\section{Electrochemical characterization}

Cyclic voltammograms of the two biohybrids were recorded thanks to the fabrication of modified electrodes based on multi-wall carbon nanotubes (MWCNTs) on which the biohybrids were adsorbed. $^{70,71}$ Coating of the resulting electrodes with Nafion significantly increased the stability of the resulting electrodes which otherwise immediately released the biohybrid into the electrolyte solution. The cyclic voltammogram of $S w \mathrm{Mb} \cdot \mathbf{1}$ immobilized on MWCNTs recorded in Tris-HCl pH 7.5 buffer (Figure 10) displayed a reversible system at $-0.48 \mathrm{~V}$ vs SHE which can be assigned to the $\mathrm{Co}(\mathrm{II}) / \mathrm{Co}(\mathrm{I})$ couple of complex 1 accommodated in $S w \mathrm{Mb}$. The cyclic voltammogram of a millimolar solution of $\mathbf{1}$ recorded on the same MWCNTs electrode (Figure 10) displays a reversible signal at $-0.38 \mathrm{~V}$ vs SHE, i.e. the $\mathrm{Co}(\mathrm{II}) / \mathrm{Co}(\mathrm{I})$ couple in $S w \mathrm{Mb} \cdot \mathbf{1}$ is located $100 \mathrm{mV}$ more negative than for $\mathbf{1}$ alone. ${ }^{72}$ By contrast, addition of imidazole (10 equiv.) to a solution of $\mathbf{1}$ shifts the redox potential of the $\operatorname{Co}(\mathrm{II} / \mathrm{Co}(\mathrm{I})$ couple more positive, although to a lower extent (40 $\mathrm{mV}$, Figure S6). This indicates that the redox properties of $\mathbf{1}$ in $S w \mathrm{Mb} \cdot \mathbf{1}$ is controlled not only by coordination of the His ligand but also modulated by second coordination sphere interactions or specific dielectric constant experienced by the complex within the protein framework. A specific effect of His coordination may be seen in the disappearance of the $\mathrm{Co}$ (III)/Co(II) signal ${ }^{73}$ in the cyclic voltammogram of $S w \mathrm{Mb} \cdot \mathbf{1}$, paralleling the modification observed when imidazole is added to an aqueous solution of $\mathbf{1}$ (Figure S6). The cyclic voltammogram of $S w \mathrm{Mb} \cdot \mathbf{2}$ is shown in Figure S7. It displays an ill-defined and irreversible signal at $-0.38 \mathrm{~V}$ vs SHE tentatively assigned to the $\mathrm{Co}(\mathrm{III}) / \mathrm{Co}(\mathrm{II})$ couple of the $\left\{\mathrm{Co}(\mathrm{dmgH})_{2}\left(\mathrm{H}_{2} \mathrm{O}\right) \mathrm{His}\right\}$ moiety by comparison with the cyclic voltammogram of $\left[\mathrm{Co}(\mathrm{dmgH})_{2} \mathrm{Cl}(\mathrm{py})\right] .{ }^{12}$ No signal for the $\mathrm{Co}(\mathrm{II}) / \mathrm{Co}(\mathrm{I})$ could be identified since this is overlapped by a large, probably catalytic, wave with onset at $-0.6 \mathrm{~V}$ vs SHE assigned to hydrogen evolution. 


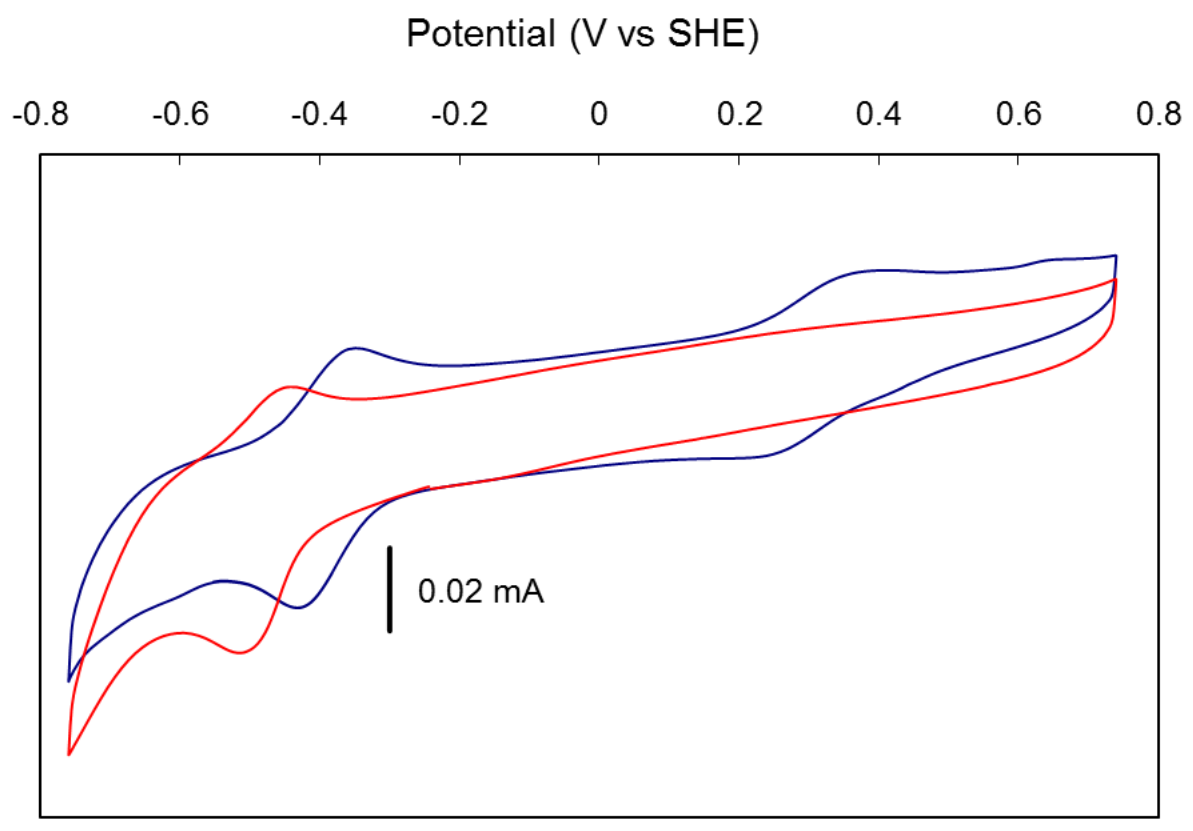

Figure 10. Cyclic voltammograms recorded in 100 mmol. $\mathrm{L}^{-1}$ Tris- $\mathrm{HCl} \mathrm{pH} 7.5$ buffer, $100 \mathrm{mmol.L^{- }}$ ${ }^{1} \mathrm{NaCl}$ of $S w \mathrm{Mb} \cdot \mathbf{1}$ adsorbed on MWCNTs and coated with Nafion (red trace) and a solution of $\mathbf{1}$ (1 mmol.L ${ }^{-1}$, blue trace). Scan rate $100 \mathrm{mV} \cdot \mathrm{s}^{-1}$.

\section{Catalytic activity}

The capability of both biohybrids for catalytic $\mathrm{H}_{2}$ evolution from aqueous solutions at $\mathrm{pH} 7.0$ was first assessed using the europium(II) complex $\left[\mathrm{Eu}(\mathrm{EGTA})\left(\mathrm{H}_{2} \mathrm{O}\right)\right]^{2-}\left(10\right.$ equiv., $\left.0.1 \mathrm{mmol} . \mathrm{L}^{-1}\right)$. Hydrogen concentration in the solution was monitored with a Unisense micro-Clark electrode as shown in Figure 11 for experiments carried out with $S w \mathrm{Mb} \cdot \mathbf{2}$ and $\mathbf{2}$ as the catalysts. Data are collected in Table 3. Under these conditions, in the case of $S w \mathrm{Mb} \cdot \mathbf{2}$, the reductant was consumed in about 5 min. generating $\mathrm{H}_{2}$ with a $65 \%$ yield, corresponding to 3.2 turnovers (TON). $S w \mathrm{Mb} \cdot \mathbf{2}$ slightly outperformed $\mathbf{2}$, as far as the total TON is concerned, even if a slower initial reaction rate was observed (Figure 11). Hydrogen evolution could be restarted, though with a lower efficiency, via addition of $\mathrm{Eu}(\mathrm{II})$. By comparison, $S w \mathrm{Mb} \cdot \mathbf{1}$ only achieved $0.3 \mathrm{TON}$ under the same conditions, which was significantly lower than $\mathbf{1}$ (2 TONs).

Hydrogen evolution (Table 3) was also studied under photocatalytic conditions at $\mathrm{pH}$ 7.0, using deazaflavin (DAF) as photosensitizer, whose excited state can capture an electron and a proton from the Tris- $\mathrm{HCl}$ buffer, thus generating the radical species $\mathrm{DAFH}^{\cdot}{ }^{74-77}$ This radical dimerizes spontaneously, but the latter reaction is reversible under light irradiation generating a steady-state concentration of the reductive $\mathrm{DAFH}^{*}$ that can then transfer an electron to the Co-based catalyst. 
Under these conditions (Table 3), the catalytic performances of the two biohybrids were very close to those obtained at the same $\mathrm{pH}$ when $\left[\mathrm{Eu}(\mathrm{EGTA})\left(\mathrm{H}_{2} \mathrm{O}\right)\right]^{2-}$ was used as the reductant. Larger TONs (3.8 and 3 TONs for $S w \mathrm{Mb} \cdot \mathbf{1}$ and $S w \mathrm{Mb} \cdot \mathbf{2}$ respectively, Table 3) were obtained for $S w \mathrm{Mb} \cdot \mathbf{1}$ under photocatalytic conditions at $\mathrm{pH} 6$ in a phosphate buffer, using $\left[\mathrm{Ru}(\mathrm{bipy})_{3}\right]^{2+}$ as photosensitizer and ascorbate as a sacrificial electron donor. Under these conditions, photocatalytic proton reduction likely commences with the reductive quenching of photo-excited $\left[\mathrm{Ru}(\text { bipy })_{3}\right]^{2+}$ by ascorbate, generating $\left[\mathrm{Ru}^{\mathrm{II}}(\text { bipy })_{2}\left(\text { bipy }^{\circ}\right)\right]^{+}$, a potent reductant $\left(\mathrm{E}^{0}=-1.12 \mathrm{~V}\right.$ vs SHE), with a lifetime of $~ 500 \mathrm{~ns}$ under these conditions. Then electron transfer to the Co-based catalyst can proceed, in competition with charge recombination between $\left[\mathrm{Ru}(\mathrm{bipy})_{3}\right]^{+}$and oxidized ascorbate, both of which can be expected to occur at rates close to the diffusion limit. In all cases (thermal reduction by the Eu(II) complex or photocatalytic conditions) the blue color of the $\mathrm{Co}(\mathrm{I})$ species $^{78}$ is observed immediately after addition of the reducing agent, which supports the above mechanisms. It should be noted that the confinement of the cobaloxime within the myoglobin cavity strongly constrains the mechanism of the $\mathrm{H}_{2}$ evolution reaction, which may account for the lower activity observed for the biohybrids. Indeed, two mechanisms may occur in parallel for the free complex: in the first one, involving only one metal site, $\mathrm{H}_{2}$ is produced via the protonation of a metal-bound hydride ligand; the second one involves bimolecular $\mathrm{H}_{2}$ elimination from two metal-hydride molecules and is fully excluded in the case of the biohybrid species. ${ }^{10}$

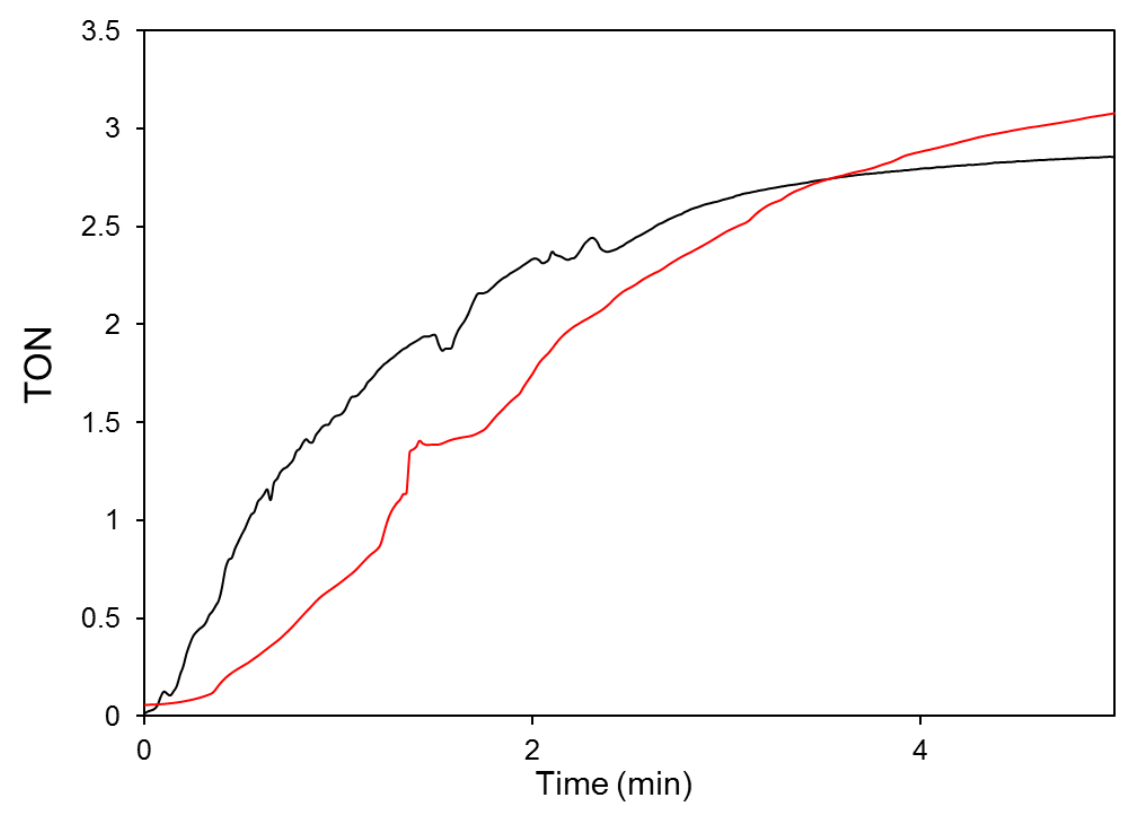


Figure 11. Catalytic $\mathrm{H}_{2}$ evolution from $\mathrm{pH} 7.0$ aqueous solution of [Eu(EGTA)] (10 equiv. with respect to the biohybrid) in Tris- $\mathrm{HCl}$ buffer ) in the presence of $\mathrm{Sw} \mathrm{Mb} \cdot \mathbf{2}$ (red trace) and 2 (black trace). Both catalysts were at a $10 \mu$ mol. $\mathrm{L}^{-1}$ concentration. $\mathrm{H}_{2}$ concentration was monitored using a Unisense micro-Clark electrode.

Table 3. Catalytic $\mathrm{H}_{2}$ evolution mediated by $S w \mathrm{Mb} \cdot \mathbf{1}, S w \mathrm{Mb} \cdot \mathbf{2}, \mathbf{1}$ and $\mathbf{2}$ under various conditions. TONs are calculated versus the number of introduced Co centers.

\begin{tabular}{cccc}
\hline Compound & & \multicolumn{2}{c}{ TON } \\
& $\begin{array}{c}\text { [Eu(EGTA })(\mathrm{H} 2 \mathrm{O})]^{2-} \\
\mathrm{pH} 7\end{array}$ & $\begin{array}{c}\mathrm{h} / \mathrm{DAF} / \mathrm{Tris} \\
(\mathrm{pH} 7)\end{array}$ & $\left(\mathrm{RH}(\mathrm{bipy})_{3}\right]^{2+} /$ ascorbate \\
\hline $\mathbf{1}$ & 2 & 2 & 5 \\
$\mathbf{2}$ & 2.5 & 8.3 & 7 \\
$S w \mathrm{Mb} \cdot \mathbf{1}$ & 0.3 & 0.6 & 3.8 \\
$S w \mathrm{Mb} \cdot \mathbf{2}$ & 3.2 & 5 & 3 \\
\hline
\end{tabular}

\section{DISCUSSION}

Sperm-whale myoglobin $(S w \mathrm{Mb})$ has been used as a host protein for the construction of a variety of artificial enzymes that catalyze oxidation of organic substrates. Schiff-base complexes of chromium(III), ${ }^{33,34}$ manganese(III),${ }^{34,35}$ iron(III) ${ }^{32}$ and copper(II) ${ }^{36}$ have been inserted within the cavity of the apo-Sw Mb host where they bind to a histidine residue. In most cases His93, which is the natural ligand of hemin in holo- $S w \mathrm{Mb}$, coordinates the square planar Schiff-base complexes in the axial position, as revealed by X-ray crystallography. ${ }^{32}$ Cobaloximes possess square-planar geometry similar to Schiff-base complexes together with good affinity in their axial position for $\mathrm{N}$-heterocyclic bases. Accordingly, the two cobaloximes $\mathbf{1}$ and $\mathbf{2}$ used in this study form pure, molecularly defined and stable biohybrids, $S w \mathrm{Mb} \cdot \mathbf{1}$ and $S w \mathrm{Mb} \cdot \mathbf{2}$, upon reaction with apo-SwMb. All spectroscopic data confirm that the cobaloximes are inserted within the binding pocket of the folded $S w \mathrm{Mb}$ protein and are coordinated to a histidine residue in the axial position of the cobalt complex, resulting in a very high association constant. QC/MM docking calculations indicated coordination preference for His93 over the other histidine residue (His64) present in the vicinity. Structural data extracted from these calculations fit well with those obtained from EXAFS measurements on both biohybrids. In both cases, the cobalt center appears to be hexacoordinated with a water molecule completing the coordination sphere of the cobaloxime complexes bound to 
the protein via axial His93. In the case of $S w \mathrm{Mb} \cdot 2$, the coordinated water molecule is hydrogenbonded to His 64 .

The hydrophobic environment of the cobaloxime when inserted within the myoglobin cavity is demonstrated by the comparison of the g-values extracted from EPR spectra of $S w \mathrm{Mb} \cdot \mathbf{1}$ with those already reported for the $\left\{\mathrm{Co}\left(\mathrm{dmgBF}_{2}\right)_{2}\right\}$ moiety in various compounds or media (Table 1). The graphical representations shown in Figure 12 indeed shows two distinct correlation features between $g_{x}$ and $g_{y}$ on one side and $g_{x}$ and $A_{z}$ on the other side depending on the nature of the medium (protic and polar -red lines- or aprotic and apolar -blue lines). The g-values and hyperfine coupling constants with ${ }^{59} \mathrm{Co}$ and ${ }^{14} \mathrm{~N}$ nuclei measured for $S w \mathrm{Mb} \cdot \mathbf{1}$ are close to the blue lines in both representations. In particular the observed values are very similar to the values measured in toluene, a very hydrophobic environment, for an adduct between $\left\{\mathrm{Co}\left(\mathrm{dmgBF}_{2}\right)_{2}\right\}$ and a pyridylmodified perylene diimide (p-PDI, N-cyclohexyl-N'-4-pyridyl-1,7-dipyrrolidinylperylene3,4:9,10-tetracarboxylic acid bisimide). ${ }^{79}$ p-PDI coordinates axially to the cobaloxime through a pyridine moiety, thus mimicking histidine coordination in the biohybrid. Such correlations will be highly valuable to characterize the immediate environment of the cobaloxime moieties in related protein systems such as the photosystem I-based hybrid complex, for example. ${ }^{31}$ 

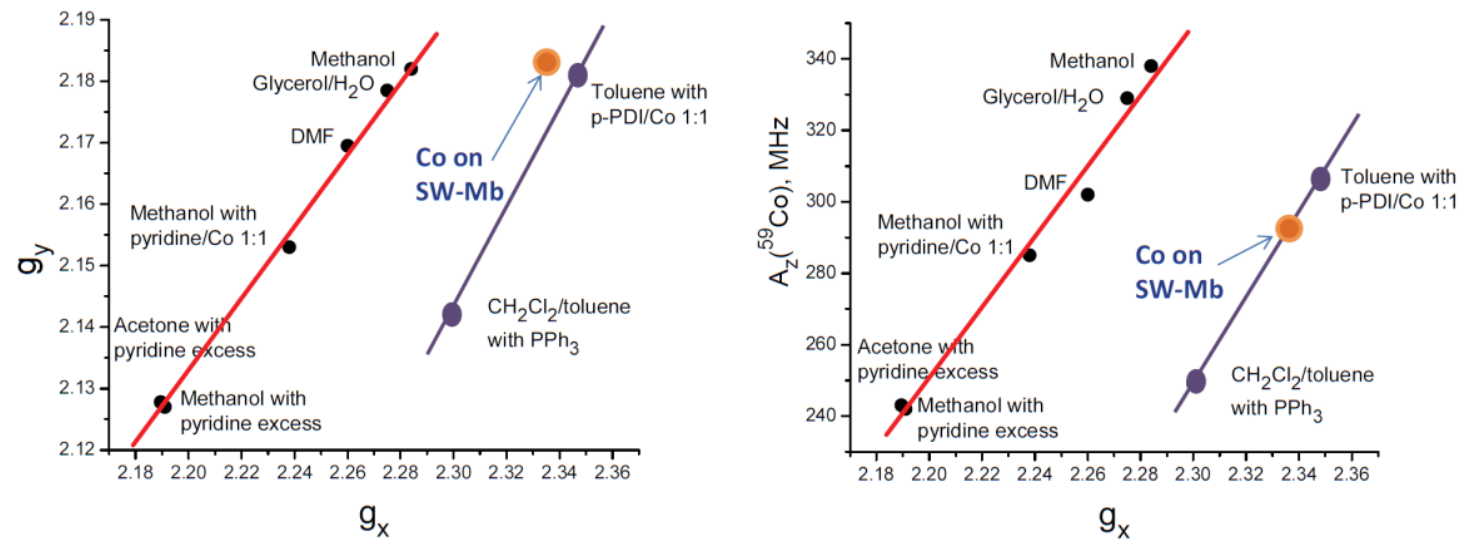

Figure 12. Correlation plots of $\mathrm{g}_{\mathrm{y}}$ and $|\mathrm{Az}|\left({ }^{59} \mathrm{Co}\right)$ vs $\mathrm{g}_{\mathrm{x}}$ for the $\left\{\mathrm{Co}\left(\mathrm{dmgBF}_{2}\right)_{2}\right\}$ moiety in different solvents. All parameters besides those for the $S w \mathrm{Mb} \cdot \mathbf{1}$ biohybrid have been taken from previous work. $^{61}$

All these data provide clear evidence that the cobaloxime is bound in the apo-myoglobin heme pocket and is coordinated to only one of the two histidines available in the binding pocket. No other interactions with amino-acids residues located in the pocket could be evidenced from the docking study, but we note that the cobaloxime ligands lack the propionate and ethyl residues that stabilize the heme cofactor in myoglobin through hydrogen bonds and hydrophobic interactions respectively.

Electrochemical measurements on biohybrid-modified CNT electrodes demonstrated redox activity of the cobalt centers in both biohybrids. The potential of the $\operatorname{Co}(\mathrm{II}) / \mathrm{Co}(\mathrm{I})$ couple is 
significantly affected by the protein environment with a $100 \mathrm{mV}$ negative shift. In the case of $S w \mathrm{Mb} \cdot \mathbf{2}$, the cyclic voltammogram recorded at $\mathrm{pH} 7$ suggests catalytic activity for $\mathrm{H}_{2}$ evolution with onset potential at -0.6 vs SHE thus corresponding to an overpotential requirement of $\sim 200$ $\mathrm{mV}$. Because the low stability of the biohybrid-modified CNT electrodes prevented detailed electrocatalytic studies, we turned to solution assays to assess the catalytic properties of the biohybrids. We used two different sets of conditions at $\mathrm{pH} 7.0$ based either on thermal reduction of the catalyst by the $\mathrm{Eu}(\mathrm{II})$ complex $\left[\mathrm{Eu}(\mathrm{EGTA})\left(\mathrm{H}_{2} \mathrm{O}\right)\right]^{2-}$ reductant $\left(\mathrm{E}_{\mathrm{Eu}(\mathrm{II}) / \mathrm{Eu}(\mathrm{III})}^{0}=-0.88\right.$ vs SHE corresponding to $\mathrm{E}_{\mathrm{Eu}(\mathrm{II} / \mathrm{Eu}(\mathrm{III})}=-0.64--0.70 \mathrm{vs} \mathrm{SHE}$ at the $\mathrm{Eu}^{\mathrm{II}}$ concentrations used in this study; ${ }^{80}$ the driving force for $\mathrm{H}_{2}$ evolution is $\sim 220-280 \mathrm{mV}$ ) or light-driven reduction of the catalyst by photogenerated $\mathrm{DAFH}^{\bullet}$ radical $\left(\mathrm{E}^{0}=-0.65 \mathrm{~V}\right.$ vs SHE; the driving force for $\mathrm{H}_{2}$ evolution is $\sim 240$ $\mathrm{mV}$ ). In both case, the driving force for catalysis is thus only slightly higher than the overpotential requirement indicated by $\mathrm{CV}$ measurements. Accordingly $S w \mathrm{Mb} \cdot \mathbf{2}$ displays catalytic activity both under thermal reduction by the $\mathrm{Eu}(\mathrm{II})$ complex and in photocatalytic conditions.

By contrast $S w \mathrm{Mb} \cdot \mathbf{1}$ proved mostly inactive at $\mathrm{pH}$ 7. This decrease in activity in the biohybrid as compared to complex 1 could be related to the $100 \mathrm{mV}$ cathodic shift of the $\mathrm{Co}(\mathrm{II}) / \mathrm{Co}(\mathrm{I})$ process induced by the incorporation of the complex in the protein. Decreasing the $\mathrm{pH}$ value to 6 and using $\left[\mathrm{Ru}(\text { bipy })_{3}\right]^{2+}$ as the photosensitizer and ascorbate as a sacrificial electron donor allowed the observation of catalytic activity for $S w \mathrm{Mb} \cdot \mathbf{1}$ (TON $=3.8$ ). The requirement for acidic $\mathrm{pH}$ for catalytic $\mathrm{H}_{2}$ evolution in the case of complex 1 has been reported prior to this study. Connolly and Espenson initially reported efficient $\mathrm{H}_{2}$ evolution activity for $\mathbf{1}$ using $\mathrm{Cr}^{\mathrm{II}}, \mathrm{V}^{\mathrm{II}}$ or Eu ${ }^{\mathrm{II}}$ salts as electron sources in $\mathrm{HCl}$ solution $(\mathrm{pH}<1) .{ }^{19}$ A further report from Szajna-Fuller and $\mathrm{Bakac}^{20}$ using $\mathrm{Ti}^{\mathrm{iII}}$-citrate as the electron source demonstrated that no activity could be observed at $\mathrm{pH}>4$. Our results thus confirm the previous observation that only proton-bridged cobaloximes (related to complex 2) can act as catalysts for $\mathrm{H}_{2}$ evolution in neutral to basic conditions. ${ }^{22,24,31}$ More acidic conditions $(\mathrm{pH}<5)$ would probably allow to increase the $\mathrm{H}_{2}$-evolving catalytic activity of $S w \mathrm{Mb} \cdot \mathbf{1}$. Unfortunately, myoglobin is not stable under such conditions where defolding occurs and the cofactor is released into solution.

With an overpotential requirement in the $200 \mathrm{mV}$ range, cobaloxime-based artificial hydrogenase thus prove competitive with cobalt porphyrin-based biohybrids which require much higher driving force $(>800 \mathrm{mV})$ to catalyze $\mathrm{H}_{2}$ evolution at $\mathrm{pH} 7 .^{81}$ They are unfortunately much less stable during turn-over, probably because reduction of the dioxime ligands leads to their irreversible hydrogenation (and inactivation of the catalyst) while porphyrins can act as reversible electron reservoirs. 
The two novel artificial hydrogenases $S w \mathrm{Mb} \cdot \mathbf{1}$ and $S w \mathrm{Mb} \cdot \mathbf{2}$ however compare well with other artificial enzymes based on dithiolate-bridged hexacarbonyl diiron catalytic units covalently attached to polypeptides ${ }^{82-84}$ or incorporated within cytochrome c. ${ }^{85,86}$ In these systems, larger polypeptides were found to enhance catalytic activities, pointing to the importance of the whole protein environment, as described in this study. Such biohybrid systems were shown to catalyze light-driven $\mathrm{H}_{2}$ evolution in aqueous conditions and in the presence of $\left[\mathrm{Ru}(\mathrm{bpy})_{3}\right]^{2+}$ as the photosensitizer and ascorbate as the sacrificial electron donor, resulting in total TONs of 5 to 9 (with regard to the catalyst) at neutral to basic $\mathrm{pH} .{ }^{87}$ The reason for such a limited stability may be drawn from mechanistic considerations. In the case of cobaloxime-mediated $\mathrm{H}_{2}$ evolution, the catalytic mechanism starts with the protonation of a $\mathrm{Co}(\mathrm{I})$ species, yielding a $\mathrm{Co}(\mathrm{III})-\mathrm{H}$ species. ${ }^{10}$ We note that a blue color assigned to a $\mathrm{Co}(\mathrm{I})$ or a $\mathrm{Co}(\mathrm{III})-\mathrm{H}$ species $^{78}$ is initially observed in the catalytic assays involving $S w \mathrm{Mb} \cdot \mathbf{1}$ and $S w \mathrm{Mb} \cdot \mathbf{2}$. Reduction of this $\mathrm{Co}(\mathrm{III})-\mathrm{H}$ species is however required for catalysis to occur. Hydrogen is then heterolytically produced through rapid protonation of a $\mathrm{Co}(\mathrm{II})-\mathrm{H}$ species. ${ }^{88-90}$ The limited stability observed upon turn-over likely originates from deactivation of a catalytic intermediate such as the $\mathrm{Co}(\mathrm{III})-\mathrm{H}$ species. It has been proposed that hydride transfer from this latter species results in the hydrogenation of the glyoximato ligand with loss of catalytic activity. ${ }^{91}$ Thus a higher activity and stability would be expected if the delay between the two successive electron transfer processes could be limited. Such fast electron injection is likely to occur in the photosystem I/cobaloxime biohybrid system and explains its exceptional stability. ${ }^{31}$ Similar supramolecular control of the electronic communication between the photosensitizer and catalytic unit within artificial enzymes had been proven beneficial in the case of dithiolate-bridged hexacarbonyl diiron catalytic units ${ }^{86}$ and nickel bisdiphosphine complexes. $^{92}$

\section{CONCLUSION}

A number of metallocenters have been incorporated into sperm whale myoglobin (and other heme proteins) to create functional catalysts. ${ }^{30}$ Surprisingly, this strategy has only ben applied to oxidation catalysts and never been used to prepare artificial hydrogenases. ${ }^{629}$ We show here that cobaloxime can be easily installed in myoglobin through coordination to only one of the two histidines available in the binding pocket. The resulting biohydrids display catalytic activity for $\mathrm{H}_{2}$ evolution under aqueous conditions and with low overpotential requirement $(\sim 200 \mathrm{mV})$, which is key for further biotechnological application since this parameter directly impacts the energetic 
efficiency of electrochemical devices. The operational stability, another crucial requirement for technological implementation, appears limited to few turnovers, as observed for most artificial hydrogenases described so far. This could however be improved through enhanced electron communication with the electron donor as discussed above or active site engineering. The latter has previously been achieved for other artificial metalloenzymes, ${ }^{28,93,94}$ some based on the myoglobin scaffold, ${ }^{32,33,95}$ either through point mutation or exploration of the diversity of hemoproteins that could bind these and other synthetic Co catalysts.

\section{ASSOCIATED CONTENT}

\section{Supporting Information}

Full experimental details and additional Figures S1-S7: UV-visible spectra, EPR spectra, electrochemical data and representation of calculated structures. This material is available free of charge via the Internet at http://pubs.acs.org.

\section{AUTHOR INFORMATION}

\section{Corresponding Author}

*E-mail vincent.artero@ @ea.fr; tel +33438789106 (V.A.).

\section{Notes}

The authors declare no competing financial interest.

\section{ACKNOWLEDGEMENTS}

The authors acknowledge partial support from the French National Research Agency (ANR, Labex program ARCANE, ANR-11-LABX-0003-01), the COST Action CM1202 PERSPECT$\mathrm{H}_{2} \mathrm{O}$ and the Life Science Division of the CEA (Irtelis and 2011 DSV-Energy programs). GB gratefully acknowledges support from Bengt Lundqvist minnesfond, FORMAS (contract no. 2132010-563) and the Swedish royal academy of sciences. Work at the Argonne National Laboratory was supported by funding from the Division of Chemical Sciences, Biosciences, Office of Basic Energy Sciences of the U.S. Department of Energy through Grant DE-AC02-06CH11357. The authors thank Sunshine Silver (Argonne national Laboratory) for ICP-AOS measurements.

\section{REFERENCES}

(1) Armstrong, F. A.; Hirst, J. Proc. Natl. Acad. Sci. USA 2011, 108, 14049-14054.

(2) Madden, C.; Vaughn, M. D.; Diez-Perez, I.; Brown, K. A.; King, P. W.; Gust, D.; Moore, A. L.; Moore, T. A. J. Am. Chem. Soc. 2012, 134, 1577-1582. 
(3) Jones, A. K.; Sillery, E.; Albracht, S. P. J.; Armstrong, F. A. Chem. Commun. 2002, 866-867.

(4) Canaguier, S.; Artero, V.; Fontecave, M. Dalton Trans. 2008, 315-325.

(5) Tard, C.; Pickett, C. J. Chem. Rev. 2009, 109, 2245-2274.

(6) Simmons, T. R.; Berggren, G.; Bacchi, M.; Fontecave, M.; Artero, V. Coord. Chem. Rev. 2014, 270-271, 127-150.

(7) Chenevier, P.; Mugherli, L.; Darbe, S.; Darchy, L.; DiManno, S.; Tran, P. D.; Valentino, F.; Iannello, M.; Volbeda, A.; Cavazza, C.; Artero, V. C. R. Chim. 2013, 16, 491-516.

(8) Fontecave, M.; Artero, V. C. R. Chim. 2011, 14, 362-371.

(9) DuBois, M. R.; DuBois, D. L. Chem. Soc. Rev. 2009, 38, 62-72.

(10) Artero, V.; Chavarot-Kerlidou, M.; Fontecave, M. Angew. Chem. Int. Ed. 2011, 50, 7238-

7266.

(11) Baffert, C.; Artero, V.; Fontecave, M. Inorg. Chem. 2007, 46, 1817-1824.

(12) Razavet, M.; Artero, V.; Fontecave, M. Inorg. Chem. 2005, 44, 4786-4795.

(13) Hu, X.; Brunschwig, B. S.; Peters, J. C. J. Am. Chem. Soc. 2007, 129, 8988-8998.

(14) Hu, X. L.; Cossairt, B. M.; Brunschwig, B. S.; Lewis, N. S.; Peters, J. C. Chem. Commun. 2005, $4723-4725$

(15) Fourmond, V.; Jacques, P. A.; Fontecave, M.; Artero, V. Inorg. Chem. 2010, 49, 1033810347.

(16) Jacques, P.-A.; Artero, V.; Pécaut, J.; Fontecave, M. Proc. Natl. Acad. Sci. U.S.A. 2009, 106, 20627-20632.

(17) Bhattacharjee, A.; Andreiadis, E. S.; Chavarot-Kerlidou, M.; Fontecave, M.; Field, M. J.; Artero, V. Chem. Eur. J. 2013, 19, 15166-15174.

(18) McCrory, C. C. L.; Uyeda, C.; Peters, J. C. J. Am. Chem. Soc. 2012, 134, 3164-3170.

(19) Connolly, P.; Espenson, J. H. Inorg. Chem. 1986, 25, 2684-2688.

(20) Szajna-Fuller, E.; Bakac, A. Eur. J. Inorg. Chem. 2010, 2488-2494.

(21) Andreiadis, E. S.; Jacques, P.-A.; Tran, P. D.; Leyris, A.; Chavarot-Kerlidou, M.; Jousselme, B.; Matheron, M.; Pécaut, J.; Palacin, S.; Fontecave, M.; Artero, V. Nat. Chem. 2013, 5, 48-53.

(22) Probst, B.; Guttentag, M.; Rodenberg, A.; Hamm, P.; Alberto, R. Inorg. Chem. 2011, 50, 3404-3412.

(23) Guttentag, M.; Rodenberg, A.; Kopelent, R.; Probst, B.; Buchwalder, C.; Brandstatter, M.; Hamm, P.; Alberto, R. Eur. J. Inorg. Chem. 2012, 59-64.

(24) Wakerley, D. W.; Reisner, E. Phys. Chem. Chem. Phys. 2014, 16, 5739-5746.

(25) Cobo, S.; Heidkamp, J.; Jacques, P.-A.; Fize, J.; Fourmond, V.; Guetaz, L.; Jousselme, B.; Ivanova, V.; Dau, H.; Palacin, S.; Fontecave, M.; Artero, V. Nat. Mater. 2012, 11, 802-807.

(26) Lu, Y. Angew. Chem. Int. Ed. 2006, 45, 5588-601.

(27) Deuss, P. J.; den Heeten, R.; Laan, W.; Kamer, P. C. J. Chem. Eur. J. 2011, 17, 4680-4698.

(28) Heinisch, T.; Ward, T. R. Curr. Opin. Chem. Biol. 2010, 14, 184-199.

(29) Faiella, M.; Roy, A.; Sommer, D.; Ghirlanda, G. Biopolymers 2013, 100, 558-571.

(30) Yu, F.; Cangelosi, V. M.; Zastrow, M. L.; Tegoni, M.; Plegaria, J. S.; Tebo, A. G.; Mocny, C. S.; Ruckthong, L.; Qayyum, H.; Pecoraro, V. L. Chem. Rev. 2014, 114, 3495-3578.

(31) Utschig, L. M.; Silver, S. C.; Mulfort, K. L.; Tiede, D. M. J. Am. Chem. Soc. 2011, 133, 1633416337.

(32) Ueno, T.; Ohashi, M.; Kono, M.; Kondo, K.; Suzuki, A.; Yamane, T.; Watanabe, Y. Inorg. Chem. 2004, 43, 2852-2858.

(33) Ohashi, M.; Koshiyama, T.; Ueno, T.; Yanase, M.; Fujii, H.; Watanabe, Y. Angew. Chem. Int. Ed. 2003, 42, 1005-1008.

(34) Ueno, T.; Abe, S.; Yokoi, N.; Watanabe, Y. Coord. Chem. Rev. 2007, 251, 2717-2731.

(35) Carey, J. R.; Ma, S. K.; Pfister, T. D.; Garner, D. K.; Kim, H. K.; Abramite, J. A.; Wang, Z. L.; Guo, Z. J.; Lu, Y. J. Am. Chem. Soc. 2004, 126, 10812-10813.

(36) Abe, S.; Ueno, T.; Reddy, P. A. N.; Okazaki, S.; Hikage, T.; Suzuki, A.; Yamane, T.; Nakajima, H.; Watanabe, Y. Inorg. Chem. 2007, 46, 5137-5139. 
(37) Ueno, T.; Koshiyama, T.; Abe, S.; Yokoi, N.; Ohashi, M.; Nakajima, H.; Watanabe, Y. J. Organomet. Chem. 2007, 692, 142-147.

(38) Utschig, L. M.; Tiede, D. M.; Poluektov, O. G. Biochemistry 2010, 49, 9682-9684.

(39) Bakac, A.; Espenson, J. H. J. Am. Chem. Soc. 1984, 106, 5197-5202.

(40) Broomhead, J. A.; Young, C. G. Inorg. Synth. 1982, 21, 127-128.

(41) Janda, M.; Hemmerich, P. Angew. Chem. Int. Ed Engl. 1976, 15, 443-444.

(42) Weisbuch, S.; Gerard, F.; Pasdeloup, M.; Cappadoro, J.; Dupont, Y.; Jamin, M. Biochemistry 2005, 44, 7013-7023.

(43) Elliott, J. I.; Brewer, J. M. Arch. Biochem. Biophys. 1978, 190, 351-357.

(44) Poluektov, O. G.; Utschig, L. M.; Schlesselman, S. L.; Lakshimi, K. V.; Brudvig, G. W.; Kothe, G.; Thurnauer, M. C. J. Phys. Chem. B 2002, 106, 8911-8916.

(45) Stoll, S.; Schweiger, A. J. Magn. Reson. 2006, 178, 42-55.

(46) O'Reilly, J. E. Biochim. Biophys. Acta 1973, 292, 509-515.

(47) Becke, A. D. Phys. Rev. A 1988, 38, 3098-3100.

(48) Becke, A. D. J. Chem. Phys. 1993, 98, 5648-5652.

(49) Stephens, P. J.; Devlin, F. J.; Chabalowski, C. F.; Frisch, M. J. J. Phys. Chem. 1994, 98, $11623-11627$.

(50) Weigend, F.; Ahlrichs, R. Phys. Chem. Chem. Phys. 2005, 7, 3297-3305.

(51) Neese, F. Wiley Interdisciplinary Reviews: Computational Molecular Science 2011.

(52) Klamt, A.; Schuurmann, G. J. Chem. Soc., Perkin Trans. 2 1993, 799-805.

(53) Sinnecker, S.; Rajendran, A.; Klamt, A.; Diedenhofen, M.; Neese, F. J. Phys. Chem. A 2006, $110,2235-2245$.

(54) Field, M. J. J. Chem.Theory Comput. 2008, 4, 1151-1161.

(55) Li, H.; Robertson, A. D.; Jensen, J. H. Proteins: Struct., Funct., Bioinf 2005, 61, 704-721.

(56) Jorgensen, W. L.; Maxwell, D. S.; TiradoRives, J. J. Am. Chem. Soc. 1996, 118, 11225-11236.

(57) Stewart, J. J. P. J. Mol. Model. 2007, 13, 1173-1213.

(58) Tiede, D. M.; Mulfort, K. L.; Scott, A. M.; Bender, S. L.; Poluektov, O. G.; Utschig, L. M.; Chen, L. X.; Mardis, K. L. Abstracts of Papers of the American Chemical Society 2010, 240.

(59) Eliezer, D.; Yao, J.; Dyson, H. J.; Wright, P. E. Nat. Struct. Biol. 1998, 5, 148-155.

(60) Hargrove, M. S.; Barrick, D.; Olson, J. S. Biochemistry 1996, 35, 11293-11299.

(61) Niklas, J.; Mardis, K. L.; Rakhimov, R. R.; Mulfort, K. L.; Tiede, D. M.; Poluektov, O. G. J. Phys. Chem. B 2012, 116, 2943-2957.

(62) Bakac, A.; Brynildson, M. E.; Espenson, J. H. Inorg. Chem. 1986, 25, 4108-4114.

(63) Rockenbauer, A.; Budozahonyi, E.; Simandi, L. I. Dalton Trans. 1975, 1729-1737.

(64) Wirt, M. D.; Bender, C. J.; Peisach, J. Inorg. Chem. 1995, 34, 1663-1667.

(65) Schrauzer, G. N.; Lee, L. P. J. Am. Chem. Soc. 1970, 92, 1551-1557.

(66) Jones, R. D.; Summerville, D. A.; Basolo, F. Chem. Rev. 1979, 79, 139-179.

(67) Westre, T. E.; Kennepohl, P.; DeWitt, J. G.; Hedman, B.; Hodgson, K. O.; Solomon, E. I. J. Am. Chem. Soc. 1997, 119, 6297-6314.

(68) It should be noted that the distance scale obtained from the Fourier transform of the EXAFS data and displayed by Figure 8 are $0.5 \AA$ lower than the real geometric distance between the Co center and its neighbours.

(69) Megnamisibelombe, M.; Nlend, G. N.; Nuber, B. Bull. Chem. Soc. Jpn. 1992, 65, 612-614.

(70) Sun, W.; Li, X. Q.; Wang, Y.; Li, X.; Zhao, C. Z.; Jiao, K. Bioelectrochemistry 2009, 75, 170175.

(71) Zhao, G. C.; Zhang, L.; Wei, X. W.; Yang, Z. S. Electrochem. Commun. 2003, 5, 825-829.

(72) No signal is observed if complex 1 alone is deposited onto the MWCNTs and coated with Nafion under otherwise similar conditions.

(73) The absence of such a Co(III)/Co(II) signal in the CV of the biohybrid species suggests that the formation of the EPR-silent Co(III) species discussed above does not simply relies on a monoelectronic process from the $\mathrm{Co}(\mathrm{II})$ species. This also provides basis for explaining why it is not possible to convert this 
EPR-silent $\mathrm{Co}(\mathrm{III})$ state into the $\mathrm{Co}(\mathrm{II})$ state by incubating the sample with mild reductants such as sodium dithionite.

(74) Hemmerich, P.; Massey, V.; Fenner, H. FEBS Lett. 1977, 84, 5-21.

(75) Massey, V.; Hemmerich, P. Biochemistry 1978, 17, 9-16.

(76) Blankenhorn, G. Eur. J. Biochem. 1976, 67, 67-80.

(77) Duchstein, H. J.; Fenner, H.; Hemmerich, P.; Knappe, W. R. Eur. J. Biochem. 1979, 95, 167-

181.

(78) Bhattacharjee, A.; Chavarot-Kerlidou, M.; Andreiadis, E. S.; Fontecave, M.; Field, M. J.; Artero, V. Inorg. Chem. 2012, 51, 7087-7093.

(79) Mulfort, K. L.; Tiede, D. M. J. Phys. Chem. B. 2010, 114, 14572-14581.

(80) Vincent, K. A.; Tilley, G. J.; Quammie, N. C.; Streeter, I.; Burgess, B. K.; Cheesman, M. R.; Armstrong, F. A. Chem. Commun. 2003, 2590-2591.

(81) Kleingardner, J. G.; Kandemir, B.; Bren, K. L. J. Am. Chem. Soc. 2013, 136, 4-7.

(82) Jones, A. K.; Lichtenstein, B. R.; Dutta, A.; Gordon, G.; Dutton, P. L. J. Am. Chem. Soc. 2007, $129,14844-14845$.

(83) Roy, A.; Madden, C.; Ghirlanda, G. Chem. Commun. 2012, 48, 9816-9818.

(84) Roy, S.; Shinde, S.; Hamilton, G. A.; Hartnett, H. E.; Jones, A. K. Eur. J. Inorg. Chem. 2011, $1050-1055$

(85) Sano, Y.; Onoda, A.; Hayashi, T. Chem. Commun. 2011, 47, 8229-8231.

(86) Sano, Y.; Onoda, A.; Hayashi, T. J. Inorg. Biochem. 2012, 108, 159-162.

(87) The use of more acidic conditions ( $\mathrm{pH}$ 4.5-4.7) allows to observe higher turnover numbers of 80 within 2 h: Roy, A.; Madden, C.; Ghirlanda, G. Chem. Commun. 2012, 48, 9816-9818; Sano, Y.; Onoda, A.; Hayashi, T. Chem. Commun. 2011, 47, 8229-8231

(88) Muckerman, J. T.; Fujita, E. Chem. Commun. 2011, 47, 12456-12458.

(89) Solis, B. H.; Hammes-Schiffer, S. Inorg. Chem. 2011, 50, 11252-11262.

(90) Dempsey, J. L.; Winkler, J. R.; Gray, H. B. J. Am. Chem. Soc. 2010, 132, 16774-16776.

(91) Simandi, L. I.; Szeverenyi, Z.; Budozahonyi, E. Inorganic \& Nuclear Chemistry Letters 1975, $11,773-777$.

(92) Silver, S. C.; Niklas, J.; Du, P. W.; Poluektov, O. G.; Tiede, D. M.; Utschig, L. M. J. Am. Chem. Soc. 2013, 135, 13246-13249.

(93) Letondor, C.; Pordea, A.; Humbert, N.; Ivanova, A.; Mazurek, S.; Novic, M.; Ward, T. R. J. Am. Chem. Soc. 2006, 128, 8320-8328.

(94) Pordea, A.; Creus, M.; Letondor, C.; Ivanova, A.; Ward, T. R. Inorg. Chim. Acta 2010, 363, 601-604.

(95) Ueno, T.; Koshiyama, T.; Ohashi, M.; Kondo, K.; Kono, M.; Suzuki, A.; Yamane, T.; Watanabe, Y. J. Am. Chem. Soc. 2005, 127, 6556-6562.

(1) Lubitz, W.; Ogata, H.; Rüdiger, O.; Reijerse, E. Chem. Rev. 2014.

(2) Lubitz, W.; Ogata, H.; Rüdiger, O.; Reijerse, E. Chem. Rev. 2014, 114, 4081-4148.

(3) Armstrong, F. A.; Hirst, J. Proc. Natl. Acad. Sci. USA 2011, 108, 14049-14054.

(4) Madden, C.; Vaughn, M. D.; Diez-Perez, I.; Brown, K. A.; King, P. W.; Gust, D.; Moore, A. L.; Moore, T. A. J. Am. Chem. Soc. 2012, 134, 1577-1582.

(5) Jones, A. K.; Sillery, E.; Albracht, S. P. J.; Armstrong, F. A. Chem. Commun. 2002, 866-867.

(6) Canaguier, S.; Artero, V.; Fontecave, M. Dalton Trans. 2008, 315-325.

(7) Tard, C.; Pickett, C. J. Chem. Rev. 2009, 109, 2245-2274.

(8) Simmons, T. R.; Berggren, G.; Bacchi, M.; Fontecave, M.; Artero, V. Coord. Chem. Rev. 2014, 270271, 127-150.

(9) Chenevier, P.; Mugherli, L.; Darbe, S.; Darchy, L.; DiManno, S.; Tran, P. D.; Valentino, F.; Iannello, M.; Volbeda, A.; Cavazza, C.; Artero, V. C. R. Chim. 2013, 16, 491-516.

(10) Fontecave, M.; Artero, V. C. R. Chim. 2011, 14, 362-371. 
(11) DuBois, M. R.; DuBois, D. L. Chem. Soc. Rev. 2009, 38, 62-72.

(12) Artero, V.; Chavarot-Kerlidou, M.; Fontecave, M. Angew. Chem. Int. Ed. 2011, 50, 7238-7266.

(13) Baffert, C.; Artero, V.; Fontecave, M. Inorg. Chem. 2007, 46, 1817-1824.

(14) Razavet, M.; Artero, V.; Fontecave, M. Inorg. Chem. 2005, 44, 4786-4795.

(15) Hu, X.; Brunschwig, B. S.; Peters, J. C. J. Am. Chem. Soc. 2007, 129, 8988-8998.

(16) Hu, X. L.; Cossairt, B. M.; Brunschwig, B. S.; Lewis, N. S.; Peters, J. C. Chem. Commun. 2005, 47234725.

(17) Fourmond, V.; Jacques, P. A.; Fontecave, M.; Artero, V. Inorg. Chem. 2010, 49, 10338-10347.

(18) Jacques, P.-A.; Artero, V.; Pécaut, J.; Fontecave, M. Proc. Natl. Acad. Sci. U.S.A. 2009, 106, 2062720632.

(19) Bhattacharjee, A.; Andreiadis, E. S.; Chavarot-Kerlidou, M.; Fontecave, M.; Field, M. J.; Artero, V. Chem. Eur. J. 2013, 19, 15166-15174.

(20) McCrory, C. C. L.; Uyeda, C.; Peters, J. C. J. Am. Chem. Soc. 2012, 134, 3164-3170.

(21) Connolly, P.; Espenson, J. H. Inorg. Chem. 1986, 25, 2684-2688.

(22) Szajna-Fuller, E.; Bakac, A. Eur. J. Inorg. Chem. 2010, 2488-2494.

(23) Andreiadis, E. S.; Jacques, P.-A.; Tran, P. D.; Leyris, A.; Chavarot-Kerlidou, M.; Jousselme, B.; Matheron, M.; Pécaut, J.; Palacin, S.; Fontecave, M.; Artero, V. Nat. Chem. 2013, 5, 48-53.

(24) Probst, B.; Guttentag, M.; Rodenberg, A.; Hamm, P.; Alberto, R. Inorg. Chem. 2011, 50, 3404-3412.

(25) Guttentag, M.; Rodenberg, A.; Kopelent, R.; Probst, B.; Buchwalder, C.; Brandstatter, M.; Hamm, P.; Alberto, R. Eur. J. Inorg. Chem. 2012, 59-64.

(26) Cobo, S.; Heidkamp, J.; Jacques, P.-A.; Fize, J.; Fourmond, V.; Guetaz, L.; Jousselme, B.; Ivanova, V.; Dau, H.; Palacin, S.; Fontecave, M.; Artero, V. Nat. Mater. 2012, 11, 802-807.

(27) Lu, Y. Angew. Chem. Int. Ed. 2006, 45, 5588-601.

(28) Deuss, P. J.; den Heeten, R.; Laan, W.; Kamer, P. C. J. Chem. Eur. J. 2011, 17, 4680-4698.

(29) Heinisch, T.; Ward, T. R. Curr. Opin. Chem. Biol. 2010, 14, 184-199.

(30) Yu, F.; Cangelosi, V. M.; Zastrow, M. L.; Tegoni, M.; Plegaria, J. S.; Tebo, A. G.; Mocny, C. S.; Ruckthong, L.; Qayyum, H.; Pecoraro, V. L. Chem. Rev. 2014, 114, 3495-3578.

(31) Utschig, L. M.; Silver, S. C.; Mulfort, K. L.; Tiede, D. M. J. Am. Chem. Soc. 2011, 133, 16334-16337.

(32) Ueno, T.; Ohashi, M.; Kono, M.; Kondo, K.; Suzuki, A.; Yamane, T.; Watanabe, Y. Inorg. Chem. 2004, 43, 2852-2858.

(33) Ohashi, M.; Koshiyama, T.; Ueno, T.; Yanase, M.; Fujii, H.; Watanabe, Y. Angew. Chem. Int. Ed. 2003, 42, 1005-8.

(34) Ueno, T.; Abe, S.; Yokoi, N.; Watanabe, Y. Coord. Chem. Rev. 2007, 251, 2717-2731.

(35) Carey, J. R.; Ma, S. K.; Pfister, T. D.; Garner, D. K.; Kim, H. K.; Abramite, J. A.; Wang, Z. L.; Guo, Z. J.; Lu, Y. J. Am. Chem. Soc. 2004, 126, 10812-10813.

(36) Abe, S.; Ueno, T.; Reddy, P. A. N.; Okazaki, S.; Hikage, T.; Suzuki, A.; Yamane, T.; Nakajima, H.; Watanabe, Y. Inorg. Chem. 2007, 46, 5137-5139.

(37) Ueno, T.; Koshiyama, T.; Abe, S.; Yokoi, N.; Ohashi, M.; Nakajima, H.; Watanabe, Y. J. Organomet. Chem. 2007, 692, 142-147.

(38) Schrauzer, G. N.; Lee, L. P.; Sibert, J. W. J. Am. Chem. Soc. 1970, 92, 2997-3005.

(39) Eliezer, D.; Yao, J.; Dyson, H. J.; Wright, P. E. Nat. Struct. Biol. 1998, 5, 148-155.

(40) Hargrove, M. S.; Barrick, D.; Olson, J. S. Biochemistry 1996, 35, 11293-11299.

(41) Niklas, J.; Mardis, K. L.; Rakhimov, R. R.; Mulfort, K. L.; Tiede, D. M.; Poluektov, O. G. J. Phys. Chem. B 2012, 116, 2943-2957.

(42) Bakac, A.; Brynildson, M. E.; Espenson, J. H. Inorg. Chem. 1986, 25, 4108-4114.

(43) Rockenbauer, A.; Budozahonyi, E.; Simandi, L. I. Dalton Trans. 1975, 1729-1737.

(44) Wirt, M. D.; Bender, C. J.; Peisach, J. Inorg. Chem. 1995, 34, 1663-1667.

(45) Schrauzer, G. N.; Lee, L. P. J. Am. Chem. Soc. 1970, 92, 1551-1557.

(46) Jones, R. D.; Summerville, D. A.; Basolo, F. Chem. Rev. 1979, 79, 139-179.

(47) Mulfort, K. L.; Tiede, D. M. J. Phys. Chem. B. 2010, 114, 14572-14581.

(48) Westre, T. E.; Kennepohl, P.; DeWitt, J. G.; Hedman, B.; Hodgson, K. O.; Solomon, E. I. J. Am. Chem. Soc. 1997, 119, 6297-6314. 
(49) It should be noted that the distance scale obtained from the Fourier transform of the EXAFS data and displayed by Figure 8 are $0.5 \AA$ lower than the real geometric distance between the Co center and its neighbours.

(50) Megnamisibelombe, M.; Nlend, G. N.; Nuber, B. Bull. Chem. Soc. Jpn. 1992, 65, 612-614.

(51) Sun, W.; Li, X. Q.; Wang, Y.; Li, X.; Zhao, C. Z.; Jiao, K. Bioelectrochemistry 2009, 75, 170-175.

(52) Zhao, G. C.; Zhang, L.; Wei, X. W.; Yang, Z. S. Electrochem. Commun. 2003, 5, 825-829.

(53) No signal is observed if complex 1 alone is deposited onto the MWCNTs and coated with Nafion under otherwise similar conditions.

(54) The absence of such a Co(III)/Co(II) signal in the CV of the biohybrid species suggests that the formation of the EPR-silent $\mathrm{Co}$ (III) species discussed above does not simply relies on a monoelectronic process from the Co(II) species. This also provides basis for explaining why it is not possible to convert this EPR-silent Co(III) state into the Co(II) state by incubating the sample with mild reductants such as sodium dithionite.

(55) Vincent, K. A.; Tilley, G. J.; Quammie, N. C.; Streeter, I.; Burgess, B. K.; Cheesman, M. R.; Armstrong, F. A. Chem. Commun. 2003, 2590-2591.

(56) Hemmerich, P.; Massey, V.; Fenner, H. FEBS Lett. 1977, 84, 5-21.

(57) Massey, V.; Hemmerich, P. Biochemistry 1978, 17, 9-16.

(58) Blankenhorn, G. Eur. J. Biochem. 1976, 67, 67-80.

(59) Duchstein, H. J.; Fenner, H.; Hemmerich, P.; Knappe, W. R. Eur. J. Biochem. 1979, 95, 167-181.

(60) Bhattacharjee, A.; Chavarot-Kerlidou, M.; Andreiadis, E. S.; Fontecave, M.; Field, M. J.; Artero, V. Inorg. Chem. 2012, 51, 7087-7093.

(61) Jones, A. K.; Lichtenstein, B. R.; Dutta, A.; Gordon, G.; Dutton, P. L. J. Am. Chem. Soc. 2007, 129, 14844-5.

(62) Roy, A.; Madden, C.; Ghirlanda, G. Chem. Commun. 2012, 48, 9816-9818.

(63) Roy, S.; Shinde, S.; Hamilton, G. A.; Hartnett, H. E.; Jones, A. K. Eur. J. Inorg. Chem. 2011, 10501055.

(64) Sano, Y.; Onoda, A.; Hayashi, T. Chem. Commun. 2011, 47, 8229-8231.

(65) Sano, Y.; Onoda, A.; Hayashi, T. J. Inorg. Biochem. 2012, 108, 159-162.

(66) Letondor, C.; Pordea, A.; Humbert, N.; Ivanova, A.; Mazurek, S.; Novic, M.; Ward, T. R. J. Am. Chem. Soc. 2006, 128, 8320-8328.

(67) Pordea, A.; Creus, M.; Letondor, C.; Ivanova, A.; Ward, T. R. Inorg. Chim. Acta 2010, 363, 601-604. 
FOR TABLE OF CONTENT ONLY

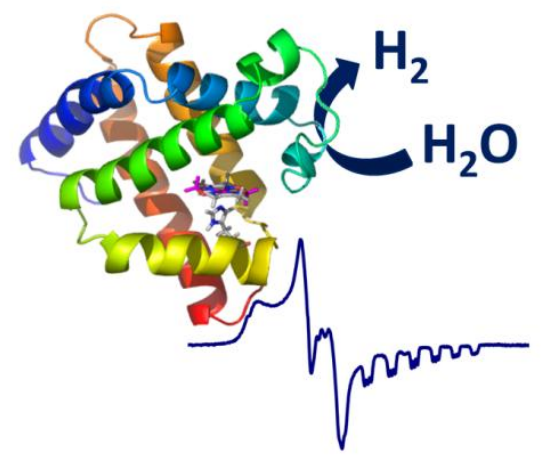

\section{Synopsis:}

Two artificial hydrogenases have been prepared through insertion of the cobaloxime moieties $\left\{\mathrm{Co}(\mathrm{dmgH})_{2}\right\}$ and $\left\{\mathrm{Co}\left(\mathrm{dmgBF}_{2}\right)_{2}\right\}\left(\mathrm{dmgH}_{2}=\right.$ dimethylglyoxime $)$ in apo Sperm-whale myoglobin $(S w \mathrm{Mb})$. Both biohybrids exhibit catalytic activity for $\mathrm{H}_{2}$ evolution in near neutral aqueous conditions. 